\title{
Inverted distribution of ductile deformation in the relatively "dry" middle crust across the Woodroffe Thrust, central Australia
}

\author{
Sebastian Wex ${ }^{1}$, Neil S. Mancktelow ${ }^{1}$, Friedrich Hawemann ${ }^{1}$, Alfredo Camacho ${ }^{2}$, and Giorgio Pennacchioni ${ }^{3}$ \\ ${ }^{1}$ Department of Earth Sciences, ETH Zurich, Sonneggstrasse 5, 8092 Zurich, Switzerland \\ ${ }^{2}$ Department of Geological Sciences, University of Manitoba, 125 Dysart Rd, Winnipeg, Manitoba, R3T 2N2, Canada \\ ${ }^{3}$ Department of Geosciences, University of Padova, Via Gradenigo 6, 35131 Padua, Italy
}

Correspondence: Neil S. Mancktelow (neil.mancktelow@erdw.ethz.ch)

Received: 31 January 2018 - Discussion started: 7 February 2018

Revised: 29 May 2018 - Accepted: 18 June 2018 - Published: 11 July 2018

\begin{abstract}
Thrust fault systems typically distribute shear strain preferentially into the hanging wall rather than the footwall. The Woodroffe Thrust in the Musgrave Block of central Australia is a regional-scale example that does not fit this model. It developed due to intracontinental shortening during the Petermann Orogeny (ca. 560-520 Ma) and is interpreted to be at least $600 \mathrm{~km}$ long in its $\mathrm{E}-\mathrm{W}$ strike direction, with an approximate top-to-north minimum displacement of $60-100 \mathrm{~km}$. The associated mylonite zone is most broadly developed in the footwall. The immediate hanging wall was only marginally involved in the mylonitization process, as can be demonstrated from the contrasting thorium signatures of mylonites derived from the upper amphibolite facies footwall and the granulite facies hanging wall protoliths. Thermal weakening cannot account for such an inverse deformation gradient, as syn-deformational $P-T$ estimates for the Petermann Orogeny in the hanging wall and footwall from the same locality are very similar. The distribution of pseudotachylytes, which acted as preferred nucleation sites for shear deformation, also cannot provide an explanation, since these fault rocks are especially prevalent in the immediate hanging wall. The most likely reason for the inverted deformation gradient across the Woodroffe Thrust is water-assisted weakening due to the increased, but still limited, presence of aqueous fluids in the footwall. We also establish a qualitative increase in the abundance of fluids in the footwall along an approx. $60 \mathrm{~km}$ long section in the direction of thrusting, together with a slight decrease in the temperature of mylonitization (ca. $100^{\circ} \mathrm{C}$ ). These changes in ambient conditions are accompanied by a 6-fold decrease in thickness (from ca. 600 to $100 \mathrm{~m}$ ) of the Woodroffe Thrust mylonitic zone.
\end{abstract}

\section{Introduction}

Continental fault and shear zone systems (e.g. Ramsay, 1980) with displacements on the order of several tens to hundreds of kilometres generally show an asymmetric mylonite distribution across the main fault horizon that is opposite for reverse faults or thrusts and normal faults or detachments. Fault zones are predicted to become more viscous and broaden with depth (e.g. Fossen and Cavalcante, 2017; Handy et al., 2007; Mancktelow, 1985; Passchier and Trouw, 2005; Platt and Behr, 2011b). The juxtaposition of initially different crustal levels should therefore result in a geometry that, for a thrust, preferentially preserves the broader ductile mylonite zone in the hanging wall, whereas, for a detachment, it should be in the footwall (e.g. Mancktelow, 1985, his Fig. 11; Passchier, 1984, his Fig. 2). This model is valid for many large-scale fault and shear zone systems, for example, the Moine Thrust Zone, NW Scotland (Christie, 1963; Coward, 1980); the Alpine Fault, New Zealand (Cooper and Norris, 1994; Sibson et al., 1981); the Saint-Barthélemy Massif shear zone, Pyrenees, southern France (Passchier, 1984); the Simplon Fault, central European Alps (Mancktelow, 1985); the Grizzly Creek shear zone, Colorado (Allen and Shaw, 2011); and the Whipple Mountains detachment fault, south-western USA (Davis, 1988; Davis and Lister, 1988). The mid- to lower-crustal Woodroffe Thrust of central Australia (Major, 1970) is an example that does not fit this model and predominantly developed a broader mylonite zone in the footwall (Bell and Etheridge, 1976; Camacho et al., 1995; Flottmann et al., 2004). An interpretation of the Woodroffe Thrust as an original detachment that was later re-oriented and exploited as a thrust can be excluded, both because the meta- 
morphic grade decreases in the direction of tectonic transport and because field mapping shows that the fault zone steepens and ramps down towards the internal part of the orogen, against the transport direction (Wex et al., 2017). Passive transport and thermal weakening also cannot account for the inverse deformation gradient, as there is no evidence for late brittle movement on the thrust plane and syn-deformational $P-T$ estimates in the hanging wall and footwall from the same locality are very similar (Wex et al., 2017). Bell and Etheridge (1976) and Camacho et al. (1995) proposed that the inverted distribution of ductile deformation is explained by the difference in bulk water content between the upper amphibolite facies $(1.0 \mathrm{wt} \%)$ footwall and the granulite facies $(0.2 \mathrm{wt} \%)$ hanging wall, reflecting the metamorphic conditions in the protolith prior to thrusting. Similarly, the preferential formation of shear zones in regions where the host rock mineralogy had previously been modified by fluidrock interaction has, for example, also been documented in the Whipple Mountains detachment fault in SE California (Selverstone et al., 2012) and the Neves area of the Tauern Window in the Eastern Alps (Mancktelow and Pennacchioni, 2005). In this paper, we discuss the control of host rock lithology and, potentially, of fluid activity on the distribution of ductile deformation across the Woodroffe Thrust, in an attempt to test the local findings of Bell and Etheridge (1976) and Camacho et al. (1995) on a more regional scale (Fig. 1). In particular, we utilize the radiogenic signature of footwall and hanging wall rocks to constrain their respective degree of reworking in the ductile mylonite zone. We also investigate the effect of varying metamorphic temperatures and fluid conditions on the change in mylonite thickness over a distance of ca. $60 \mathrm{~km}$ parallel to the direction of thrusting.

\section{Geology}

The mid- to lower-crustal Woodroffe Thrust outcrops in the Musgrave Block of central Australia (Major, 1970), which is located within the suture zone of the north, west, and south Australian cratons. These cratons were amalgamated into the Australian continent at approx. $1300 \mathrm{Ma}$ in an early stage of development of the supercontinent Rodinia (Myers et al., 1996). The Woodroffe Thrust is developed over an E-W strike length generally interpreted to exceed $600 \mathrm{~km}$ and separates the Mulga Park Subdomain in the footwall (to the north) from the Fregon Subdomain in the hanging wall (to the south) (Camacho and Fanning, 1995; Edgoose et al., 1993; Major and Conor, 1993). Exposure of the thrust is poor to inexistent in its proposed western (e.g. Stewart, 1995, 1997) and eastern (e.g. Edgoose et al., 2004) prolongations but is generally excellent for approx. $150 \mathrm{~km}$ in the central Musgrave Block (Bell, 1978; Camacho et al., 1995; Collerson et al., 1972; Wex et al., 2017), where the current study was conducted. In this region, both footwall and hanging wall predominantly consist of granitoids (more common in the footwall) and quartzo-feldspathic gneisses (more common in the hanging wall), with subordinate metadolerites, mafic gneisses, and metapelites (Fig. 1). Rare quartzites, amphibolites, and schists are restricted to the footwall $(\mathrm{Ca}-$ macho and Fanning, 1995; Collerson et al., 1972; Major, 1973; Major and Conor, 1993; Scrimgeour and Close, 1999; Young et al., 2002). Protoliths are inferred to have been felsic volcanics, sediments, and intrusives with depositional or emplacement ages around 1550 Ma (Camacho, 1997; Camacho and Fanning, 1995; Gray, 1977, 1978; Gray and Compston, 1978; Maboko et al., 1991; Major and Conor, 1993; Sun and Sheraton, 1992). These protoliths were regionally deformed and metamorphosed at upper amphibolite facies (Mulga Park Subdomain) to granulite facies (Fregon Subdomain) conditions during the ca. 1200 Ma Musgravian Orogeny (Camacho, 1997; Camacho and Fanning, 1995; Gray, 1978; Maboko et al., 1991; Sun and Sheraton, 1992) and syn- to post-tectonically intruded by the Pitjantjatjara Supersuite granitoids between ca. 1170 and $1130 \mathrm{Ma}$ (Camacho, 1997; Camacho and Fanning, 1995; Scrimgeour et al., 1999; Smithies et al., 2011). Peak temperature and pressure conditions during the Musgravian Orogeny are controversial. Earlier estimates were ca. $820-900^{\circ} \mathrm{C}$ and $1.1-$ 1.4 GPa (Ellis and Maboko, 1992; Maboko et al., 1989, 1991), but more recent studies have given conditions of ca. 800-1000 ${ }^{\circ} \mathrm{C}$ and 0.6-0.9 GPa (Camacho, 1997; Tucker et al., 2015; Walsh et al., 2015). Subsequent to this regionalscale tectono-metamorphic phase, the area experienced bimodal magmatism (Giles Complex, including the Alcurra Dolerite swarm) between ca. 1080 and $1050 \mathrm{Ma}$ and mafic magmatism (Amata Dolerite) at approx. $800 \mathrm{Ma}$ (Ballhaus and Glikson, 1995; Camacho et al., 1991; Clarke et al., 1995; Edgoose et al., 1993; Evins et al., 2010; Schmidt et al., 2006; Sun et al., 1996; Zhao et al., 1994; Zhao and McCulloch, 1993). In the area considered in the current study, gabbronorite intrusions, correlated to the Giles Complex, are restricted to the Fregon Subdomain. Except for these periods of magmatic intrusion, the central Musgrave Block remained largely unaffected by tectonic events between the Musgravian Orogeny at ca. $1200 \mathrm{Ma}$ and the Petermann Orogeny at ca. 560-520 Ma (Camacho and Fanning, 1995; Maboko et al., 1992). Earlier studies by Maboko et al. $(1989,1991)$ and Ellis and Maboko (1992) proposed that the Musgravian and Petermann orogenies represented successive stages of a single anticlockwise $P-T-t$ path, whereas Camacho (1997) and Camacho et al. $(1997,2015)$ suggested that the Musgrave Block was partially exhumed prior to the onset of the Petermann Orogeny and then reburied.

The Petermann Orogeny produced a number of large-scale mylonitic shear zones, amongst which the Woodroffe Thrust is the most prominent. Ductile deformation during top-tonorth thrusting along the Woodroffe Thrust was largely accommodated within the Mulga Park Subdomain footwall (Bell and Etheridge, 1976; Camacho et al., 1995; Flottmann et al., 2004) and is characterized by mylonites with varying 


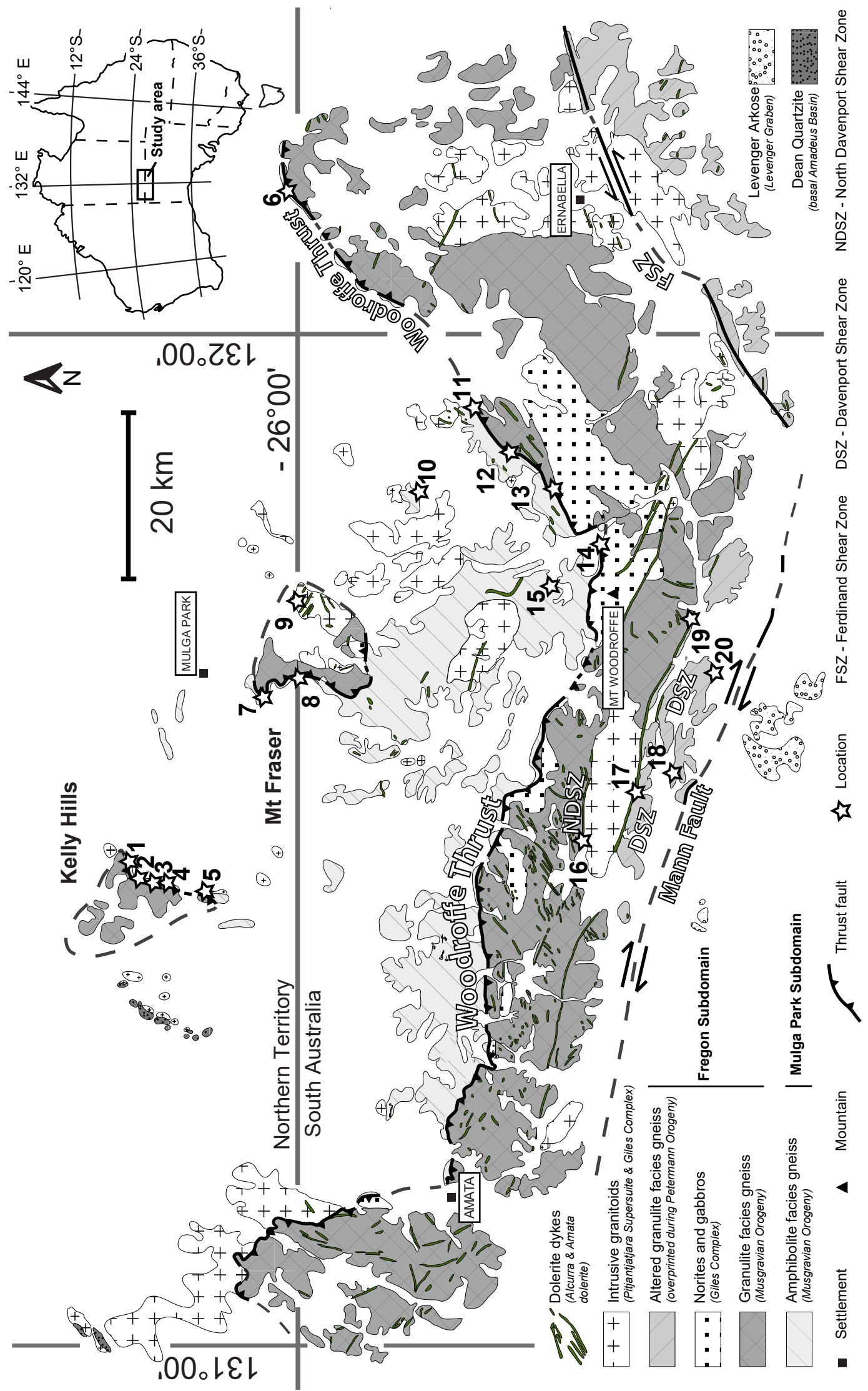

Figure 1. Geological map of the central Musgrave Block (modified after Major et al., 1967; Sprigg et al., 1959; Young et al., 2002). 


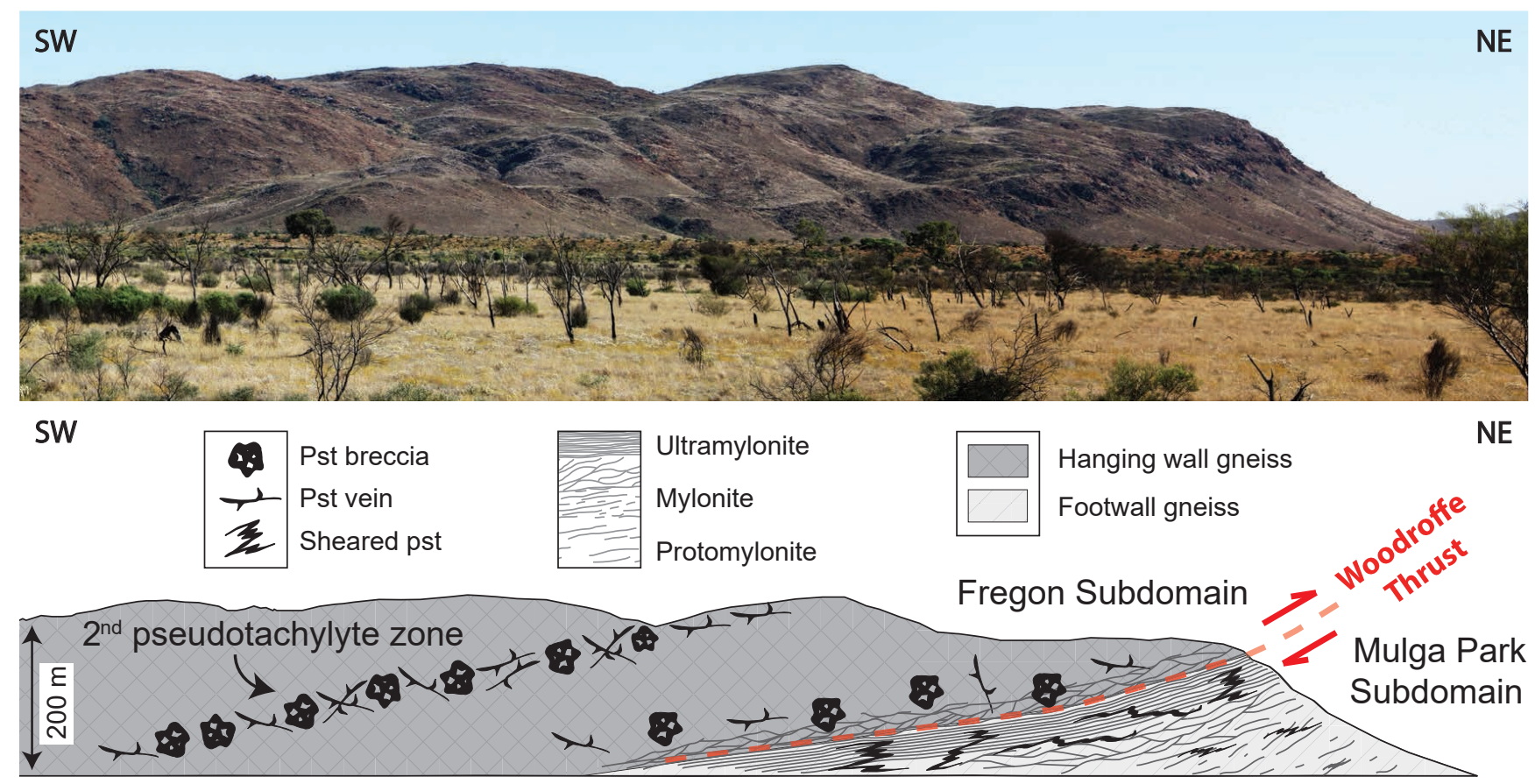

Figure 2. Photograph and schematic sketch of a cross section through the Woodroffe Thrust at Kelly Hills. Ductile deformation is almost entirely concentrated in the immediate footwall (Mulga Park Subdomain), developing a sequence of protomylonites, mylonites, and ultramylonites, with the degree of mylonitization decreasing into the footwall. In contrast, the mostly unaffected or only weakly foliated hanging wall (Fregon Subdomain) is characterized by ubiquitous and voluminous pseudotachylyte (pst) veins and breccias. Further into the hanging wall, a dip slope, characterized by a second zone of highly abundant unsheared pseudotachylyte, has also been documented. Photograph coordinates: $131.45077,-25.89823$.

degrees of strain, ranging from protomylonites to ultramylonites (Fig. 2), anastomosing around low-strain domains on the metre to kilometre scale. The syn-kinematic conditions of deformation along the Woodroffe Thrust were constrained by conventional geothermobarometry to be within the range of $520-650^{\circ} \mathrm{C}$ and $0.8-1.3 \mathrm{GPa}$ (Wex et al., 2017) and thus of lower temperature when compared to peak conditions during the earlier Musgravian Orogeny. The metamorphic assemblage in both mylonitic samples (where the metamorphic aggregate developed syn-kinematically) and in statically overprinted undeformed samples (e.g. some Alcurra and Amata Dolerite dykes) record similar metamorphic conditions, consistent with ambient mid- to lower-crustal levels (Wex et al., 2017). Stable mineral assemblages during the Petermann Orogeny in felsic units of the Woodroffe Thrust comprise (decreasing modal abundance from left to right) $\mathrm{Qz}+\mathrm{Pl}+\mathrm{Kfs}+\mathrm{Bt}+\mathrm{Ilm} \pm \mathrm{Grt} \pm \mathrm{Ep} \pm \mathrm{Ms} \pm \mathrm{Ky} \pm \mathrm{Cpx} \pm$ $\mathrm{Hbl} \pm \mathrm{Rt} \pm \mathrm{Ttn} \pm \mathrm{Mag} \pm \mathrm{Cal}$, whereas mafic units consist of $\mathrm{Pl}+\mathrm{Ilm} \pm \mathrm{Cpx} \pm \mathrm{Grt} \pm \mathrm{Rt} \pm \mathrm{Opx} \pm \mathrm{Bt} \pm \mathrm{Hbl} \pm \mathrm{Ky} \pm \mathrm{Mag}$ $\pm \mathrm{Qz} \pm \mathrm{Kfs} \pm \mathrm{Cal}$ (Wex et al., 2017). Mineral abbreviations are after Whitney and Evans (2010). The degree of mylonitization progressively decreases into the footwall but shows a very abrupt transition into the immediate, dominantly brecciated hanging wall (Figs. 2, 3), which is characterized by ubiquitous and voluminous pseudotachylyte veins and breccias (Camacho et al., 1995; Lin et al., 2005). Even though this upper boundary of the mylonites is discrete or rapidly transitional in the field (Fig. 3), it does not necessarily represent the original boundary between the Mulga Park (footwall) and Fregon (hanging wall) subdomains. In the Amata area (western edge of Fig. 1), Bell (1978) reported up to $250 \mathrm{~m}$ of marginal hanging wall reworking into the mylonite zone. However, it remains uncertain how this value was exactly determined, since hanging wall and footwall mylonites are very similar in their field appearance.

\section{Methods and general approach}

The hanging wall, footwall, and numerous transects across the Woodroffe Thrust have been studied and sampled along a $\mathrm{N}-\mathrm{S}$ traverse, parallel to the direction of thrusting. The sampling locations are reported in Fig. 1. Thin sections of the sampled mylonites were prepared from rock chips cut perpendicular to the foliation and parallel to the stretching lineation and analysed using standard polarized light and scanning electron microscopy. Firstly, the distribution of ductile deformation along and across the Woodroffe Thrust was characterized by quantifying (1) the regional variation in the maximum thickness of the mylonitic zone and (2) the associated degree of hanging wall and footwall reworking. Sec- 


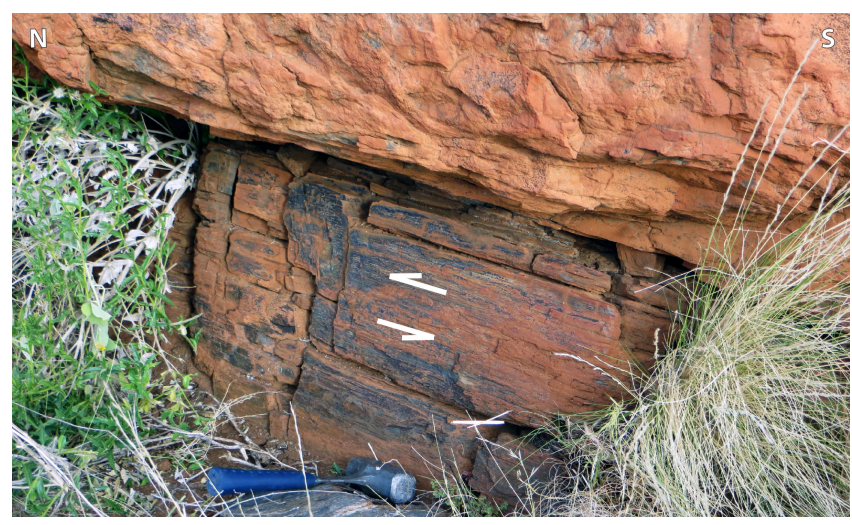

Figure 3. Sharp contact between the ultramylonites of the Woodroffe Thrust (below) and the largely undeformed felsic granulite in the hanging wall (above). Photograph looking perpendicular to the direction of thrusting. Outcrop SW13-135 (coordinates: 131.87939, -26.21188; location 12 in Fig. 1).

ondly, field and thin-section observations were compiled to assess in a qualitative manner (3) the presence/absence of fluids during deformation and (4) the regional variability in modal abundance of hydrous minerals in felsic units. Potential correlations between parameters (1) to (4) are then discussed. Sample/outcrop coordinates are given in the world geodetic system (WGS) 1984. Orientation measurements of structural elements are corrected for magnetic declination. A detailed description of all utilized methods is given in Supplement Sect. S1.

\section{Mylonite thickness}

Field observations indicate that the thickness of the Woodroffe Thrust mylonites is variable. In a section perpendicular to strike, the thickness $(T)$ of the mylonitic zone across the Woodroffe Thrust was calculated by trigonometry (Fig. 4) from (1) the angle of dip $(\alpha)$ of the thrust (measured in the field and averaged for each transect); (2) the respective difference in elevation $(p)$ (derived from the $30 \times 30 \mathrm{~m}$ digital elevation model ASTER) between the lower and upper structural boundaries of the mylonites to the unsheared country rocks (determined from field observations and remote sensing); and (3) the apparent thickness $(q)$ (derived from remote sensing). The upper boundary of the mylonitic zone is easily recognized (Fig. 3). The lower boundary is determined by the first appearance of Petermann mylonitic foliation, well characterized by the approximate $\mathrm{N}-\mathrm{S}$ trend of the stretching lineation and by the top-to-north kinematic indicators. Errors for parameters $\alpha$ and $q$ are considered negligible, whereas the $30 \times 30 \mathrm{~m}$ resolution of the digital elevation model is prone to introduce an uncertainty on the order of 10-20 m. The geometrical arrangement for the estimate of $T$ was the same for locations $2-8$ and $12-14$ (Fig. 4a) but

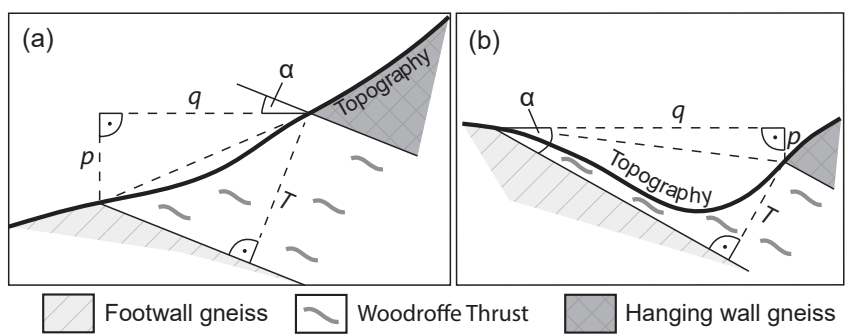

Figure 4. Schematic illustration of the trigonometry applied to quantify the true thickness of the Woodroffe Thrust mylonitic zone in a section perpendicular to strike. The parameters are defined in the main text. (a) Geometry applicable to locations 2-8 and 12-14 of Fig. 1. (b) Geometry applicable to location 11 of Fig. 1.

slightly different for location 11 (Fig. 1), where the lower structural boundary of the mylonites was at a higher elevation than the upper boundary (Fig. 4b). The thickness of the mylonitic zone at location 1 (Fig. 1) was not calculated because the Woodroffe Thrust is only exposed along-strike. The results for all other studied transects are summarized in Table 1 and, disregarding local variability, indicate a gradual increase in mylonite thickness from ca. $100 \mathrm{~m}$ in the north to ca. $600 \mathrm{~m}$ in the south.

\section{Degree of hanging wall and footwall mylonitization}

Mylonites derived from the hanging wall and footwall of the Woodroffe Thrust are very similar in both their field appearance and microstructural-petrographical characteristics. The high degree of recrystallization and general lack of porphyroclasts in the uppermost mylonites at locations 4, 6-8, and 12-14 (Fig. 1) suggest that these samples were potentially derived from the pseudotachylyte-rich Fregon Subdomain, hence indicating local hanging wall reworking. To establish whether mylonites were derived from either the Mulga Park or the Fregon subdomains, we utilized their thorium concentrations, based on the general observation that hanging wall rocks are depleted in thorium compared to footwall rocks (Fig. 5). This contrast is due to (1) dehydration and melting reactions during the earlier ca. 1200 Ma Musgravian Orogeny, which depleted the granulite facies hanging wall to a greater degree than the upper amphibolite facies footwall (Heier and Adams, 1965; Lambert and Heier, 1967, 1968), (2) the predominance of granitoids rather than gneisses in the footwall, and (3) the fact that low-thorium Giles Complex gabbro-noritic intrusions are commonly exposed in the immediate hanging wall of the Woodroffe Thrust. Deformation and metamorphism during mylonitization did not significantly alter the original thorium content of the rocks, since the thorium-bearing phases, such as zircon, allanite, monazite, and apatite, did not break down during the Petermann Orogeny. Consequently, the original variation in thorium between the granulite and amphibolite facies rocks was pre- 


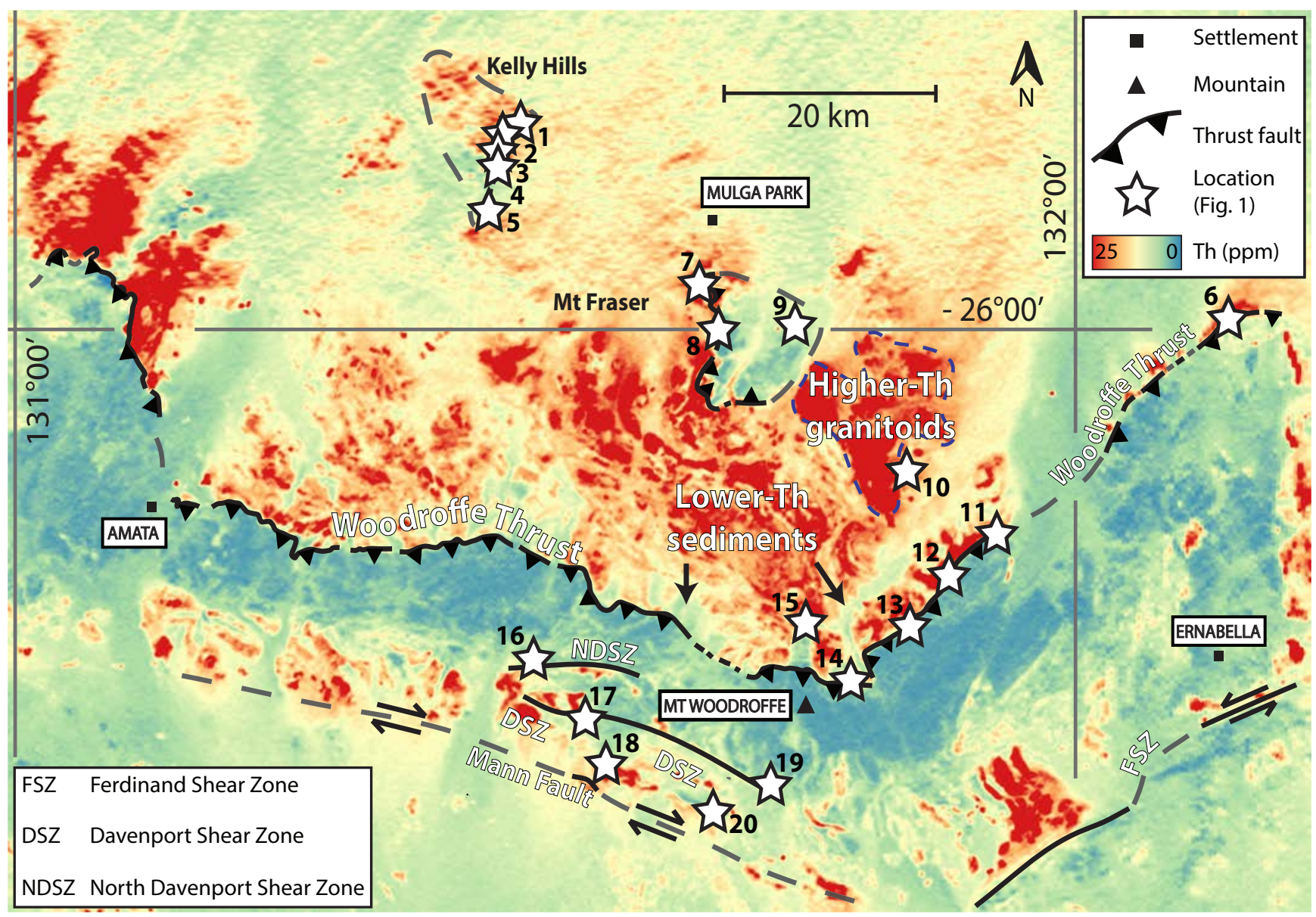

Figure 5. Airborne thorium (ppm) map of the central Musgrave Block. Data derived from the Australian Geophysical Archive Data Delivery System (GADDS) under http://www.ga.gov.au/gadds (last access: November 2013) (Percival, 2010). The hanging wall Fregon Subdomain is generally depleted compared to the footwall Mulga Park Subdomain. Granitoid intrusives of the Pitjantjatjara Supersuite often have a higher thorium content, particularly in the footwall (one example surrounded by the blue dashed line) but also in the southern part of the hanging wall. Lower-thorium signatures forming diffuse tongues extending northward into the footwall are attributed to alluvial wash derived from the hanging wall. The distinction in thorium content is no longer evident for the northernmost klippe of the hanging wall in the Kelly Hills area (locations 1-5) and the northernmost part of the Mt Fraser klippe (location 7).

Table 1. Angle of dip $(\alpha)$, elevation difference $(p)$, apparent thickness $(q)$, and true thickness $(T)$ of the Woodroffe Thrust mylonites in the central Musgrave Block.

\begin{tabular}{lrr|rrrr}
\hline $\begin{array}{l}\text { Location } \\
\text { (Fig. 1) }\end{array}$ & \multicolumn{2}{c|}{$\begin{array}{c}\text { Coordinates } \\
\text { (WGS 1984) }\end{array}$} & \multicolumn{4}{|c}{$\begin{array}{c}\text { Trigonometrical } \\
\text { parameters }\end{array}$} \\
\cline { 2 - 7 } & Longitude & Latitude & $\alpha\left(^{\circ}\right)$ & $p(\mathrm{~m})$ & $q(\mathrm{~m})$ & $T(\mathrm{~m})$ \\
\hline 2 & 131.454 & -25.845 & 27 & 22 & 150 & 88 \\
3 & 131.452 & -25.855 & 43 & 54 & 190 & 169 \\
4 & 131.449 & -25.873 & 36 & 23 & 160 & 113 \\
5 & 131.442 & -25.904 & 21 & 44 & 130 & 88 \\
6 & 132.143 & -25.992 & 29 & 62 & 160 & 132 \\
7 & 131.644 & -25.963 & 17 & 110 & 250 & 178 \\
8 & 131.663 & -25.999 & 10 & 60 & 130 & 82 \\
11 & 131.926 & -26.177 & 28 & 61 & 800 & 322 \\
12 & 131.879 & -26.212 & 24 & 153 & 430 & 315 \\
13 & 131.844 & -26.253 & 37 & 124 & 850 & 611 \\
14 & 131.774 & -26.308 & 25 & 128 & 1200 & 623 \\
\hline
\end{tabular}

served (Fig. 5). Anomalies in this broad pattern are present locally and can be attributed to hanging-wall-derived alluvial sediments in the immediate footwall (lower-thorium anomaly) and to granitoid intrusions of the Pitjantjatjara Supersuite (higher-thorium anomaly), which are syn- to postMusgravian upper amphibolite to granulite facies metamorphism (Scrimgeour and Close, 1999; Young et al., 2002) (Fig. 5). The contrast between a lower-thorium hanging wall and a higher-thorium footwall is well-defined on the airborne thorium map for the central and southern locations but less evident in the north (Fig. 5). Thorium measurements were carried out on thin-section chips of felsic gneisses and granitoids via $\gamma$-ray spectrometry, with the measurements run until the error $(2 \times$ standard deviation) was below $10 \%$. The method is outlined in detail in Supplement Sect. S1. 
Table 2. Thorium concentrations in felsic gneisses and granitoids from the hanging wall and footwall of the Woodroffe Thrust, central Musgrave Block.

Central and southern studied locations

\begin{tabular}{|c|c|c|c|c|c|c|c|}
\hline \multirow{3}{*}{$\begin{array}{c}\text { Location } \\
\text { (Fig. 1) }\end{array}$} & \multicolumn{7}{|c|}{ Hanging wall of the Woodroffe Thrust } \\
\hline & \multirow{2}{*}{ Sample } & \multirow{2}{*}{ Lithology } & \multicolumn{2}{|c|}{ Coordinates (WGS 1984) } & \multirow{2}{*}{$\begin{array}{l}\text { Data } \\
\text { source }\end{array}$} & \multirow{2}{*}{$\begin{array}{c}\text { Th } \\
\text { (ppm) }\end{array}$} & \\
\hline & & & Longitude & Latitude & & & \\
\hline 9 & SW 14-029A & granite & 131,74496 & $-26,00093$ & 1 & 6 & \\
\hline 9 & SW 14-025 & granite & 131,73269 & $-26,01569$ & 1 & 3 & \\
\hline 9 & SW 14-030B & granite & 131,74295 & $-26,00222$ & 1 & 5 & \\
\hline 17 & FW 13-173 & granite & 131,54138 & $-26,34104$ & 1 & 3 & \\
\hline 18 & FW 13-228 & granite & 131,56005 & $-26,37413$ & 1 & 28 & \\
\hline- & MP-2 & granite & 131,74845 & $-25,99871$ & 3 & 10 & \\
\hline- & MP94/500 & granite & 131,73549 & $-25,99535$ & 3 & 4 & \\
\hline- & MP94/501 & granite & 131,74105 & $-25,99389$ & 3 & 11 & \\
\hline- & $\mathrm{W}-12$ & granite & 131,55670 & $-26,38583$ & 2 & 19 & \\
\hline- & W-34d & granite & 131,52310 & $-26,34528$ & 2 & 6 & \\
\hline- & $\mathrm{W}-70$ & granite & 131,63910 & $-26,40186$ & 2 & 4 & \\
\hline- & W-96 & granite & 131,69440 & $-26,38511$ & 2 & 8 & \\
\hline- & W-104 & granite & 131,70010 & $-26,38119$ & 2 & 4 & $\Xi$ \\
\hline- & $\mathrm{W}-127$ & granite & 131,90190 & $-26,43750$ & 2 & 7 & \\
\hline- & W-146 & granite & 131,87670 & $-26,35469$ & 2 & 6 & \\
\hline- & W-148 & granite & 131,88030 & $-26,34653$ & 2 & 10 & \\
\hline- & W-199a & granite & 131,77080 & $-26,47550$ & 2 & 54 & \\
\hline- & W-199b & granite & 131,77080 & $-26,47550$ & 2 & 63 & \\
\hline- & E-37 & charnockite & 132,27078 & $-26,19010$ & 2 & 6 & $\begin{array}{l}8 \\
\infty \\
\infty\end{array}$ \\
\hline- & E-38 & charnockite & 132,26899 & $-26,18286$ & 2 & 3 & ฮี \\
\hline- & E-39 & charnockite & 132,14968 & $-26,22028$ & 2 & 2 & ర్d \\
\hline- & $\mathrm{W}-32$ & charnockite & 131,46100 & $-26,29419$ & 2 & 26 & ڤ్ర \\
\hline- & $\mathrm{W}-129$ & charnockite & 131,89100 & $-26,38531$ & 2 & 8 & ฮี \\
\hline 16 & NW 13-043 & felsic gneiss & 131,49727 & $-26,28058$ & 1 & 4 & 䓌 \\
\hline 16 & SW 13-032 & felsic gneiss & 131,49771 & $-26,28135$ & 1 & 2 & \\
\hline 19 & NW13-016B & felsic gneiss & 131,71053 & $-26,38530$ & 1 & 28 & نं \\
\hline 20 & NW 13-026 & felsic gneiss & 131,66087 & $-26,41038$ & 1 & 20 & \\
\hline 20 & NW 13-030 & felsic gneiss & 131,66258 & $-26,40675$ & 1 & 1 & \\
\hline- & E-27 & felsic gneiss & 132,14091 & $-26,18857$ & 2 & 3 & \\
\hline- & E-47 & felsic gneiss & 132,04583 & $-26,29111$ & 2 & 2 & \\
\hline- & MP97/513 & felsic gneis s & 131,66461 & $-25,97300$ & 3 & 12 & \\
\hline- & W-16dg & felsic gneiss & 131,52810 & $-26,26806$ & 2 & 6 & \\
\hline- & W-16ug & felsic gneiss & 131,52810 & $-26,26806$ & 2 & 8 & \\
\hline- & W-18 & felsic gneiss & 131,53810 & $-26,27472$ & 2 & 21 & \\
\hline- & W-122adg & felsic gneiss & 131,69830 & $-26,28992$ & 2 & 3 & \\
\hline- & W-122aug & felsic gneiss & 131,69830 & $-26,28992$ & 2 & 8 & \\
\hline- & $\mathrm{W}-140 \mathrm{~b}$ & felsic gneiss & 131,84610 & $-26,43642$ & 2 & 5 & \\
\hline- & $\mathrm{W}-142 \mathrm{a}$ & felsic gneis s & 131,84050 & $-26,44422$ & 2 & N/D & \\
\hline 8 & SW 13-191 & felsic gneiss & 131,66264 & $-25,99911$ & 1 & $\mathrm{~N} / \mathrm{D}<2$ & \\
\hline 11 & SW 14-181A & felsic gneiss & 131,92595 & $-26,17664$ & 1 & $\mathrm{~N} / \mathrm{D}<2$ & \\
\hline 11 & SW 14-182 & felsic gneiss & 131,92564 & $-26,17681$ & 1 & 1 & \\
\hline 12 & NW 13-187B & felsic gneiss & 131,87917 & $-26,21151$ & 1 & 1 & \\
\hline 12 & SW 13-135A & felsic gneiss & 131,87939 & $-26,21188$ & 1 & 2 & \\
\hline 12 & SW 13-135B & felsic gneiss & 131,87939 & $-26,21188$ & 1 & 2 & \\
\hline 12 & NW 13-189 & felsic gneiss & 131,87935 & $-26,21191$ & 1 & 2 & \\
\hline 13 & SW 14-246A & felsic gneiss & 131,84444 & $-26,25262$ & 1 & 2 & \\
\hline 14 & SW 13-164 & felsic gneiss & 131,77463 & $-26,30772$ & 1 & 3 & \\
\hline
\end{tabular}

\subsection{Thorium concentration in felsic units}

Thorium concentrations in felsic gneisses and granitoids (Table 2) have been compiled from the current study as well as from previous studies of nearby areas (Camacho, 1997; Young et al., 2002). These data have been grouped into (1) the central and southern locations and (2) the northern locations, based on the airborne thorium map, as introduced above.

\begin{tabular}{|c|c|c|c|c|c|c|c|}
\hline & & Footwall of $t$ & the Woodroff & Thrust & & & \\
\hline Location & Samnle & Litholooy & Coordinates & WGS 1984) & Data & Th & \\
\hline (Fig. 1) & & Crtiorogy & Longitude & Latitude & source & (ppm) & \\
\hline 12 & SW 13-122A & granite & 131,87206 & $-26,20364$ & 1 & 73 & ๘ \\
\hline 12 & SW 13-123 & granite & 131,87229 & $-26,20379$ & 1 & 7 & 急 \\
\hline 12 & NW13-184 & granite & 131,87823 & $-26,20914$ & 1 & 16 & 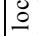 \\
\hline 12 & NW 13-185B & granite & 131,87830 & $-26,20946$ & 1 & 14 & $\bar{J}$ \\
\hline 14 & SW 13-151 & granite & 131,77438 & $-26,30117$ & 1 & 20 & $\frac{1}{2}$ \\
\hline 14 & SW 13-153 & granite & 131,77411 & $-26,30173$ & 1 & $\mathrm{~N} / \mathrm{D}<2$ & 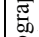 \\
\hline- & MP94/502 & granite & 131,78418 & $-25,95562$ & 3 & 55 & 0 \\
\hline- & MP94/503 & granite & 131,62926 & $-25,86096$ & 3 & 30 & $\begin{array}{l}\infty \\
\Xi\end{array}$ \\
\hline- & BJ96/178 & granite & 131,48641 & $-25,78867$ & $3^{*}$ & 18 & $\stackrel{0}{0}$ \\
\hline- & BJ96/201 & granite & 131,39771 & $-25,79945$ & $3^{*}$ & 195 & $\begin{array}{l}\mathscr{D} \\
\tilde{\Xi} \\
\tilde{\sigma}\end{array}$ \\
\hline- & BJ96/276 & granite & 131,44734 & $-25,97263$ & $3 *$ & 18 & 表 \\
\hline- & MP96/505 & granite & 131,64751 & $-25,95006$ & $3 *$ & 35 & 尝 \\
\hline- & MP96/509 & granite & 131,64996 & $-25,94452$ & 3 & 12 & $\ddot{D}$ \\
\hline 12 & SW 13-125 & felsic gneiss & 131,87338 & $-26,20470$ & 1 & 27 & ن \\
\hline- & MP97/43 & felsic gneiss & 131,81710 & $-25,98836$ & 3 & 10 & \\
\hline 8 & GW 13-415 & felsic gneiss & 131,66256 & $-25,99928$ & 1 & 15 & \\
\hline 8 & SW 13-193 & felsic gneiss & 131,66256 & $-25,99928$ & 1 & 16 & \\
\hline 8 & SW 13-192 & felsic gneiss & 131,66258 & $-25,99915$ & 1 & 23 & 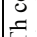 \\
\hline 11 & SW 14-179 & felsic gneiss & 131,92603 & $-26,17661$ & 1 & 15 & \\
\hline 12 & SW 13-134 & felsic gneiss & 131,87913 & $-26,21151$ & 1 & 9 & \\
\hline 13 & SW 14-243 & felsic gneiss & 131,83942 & $-26,25476$ & 1 & 8 & , \\
\hline 13 & SW 14-244 & felsic gneiss & 131,83949 & $-26,25472$ & 1 & 13 & \\
\hline 14 & SW 13-159 & felsic gneiss & 131,77375 & $-26,30666$ & 1 & 6 & ర0 \\
\hline 14 & SW 13-161 & fels ic gneiss & 131,77445 & $-26,30759$ & 1 & 14 & \\
\hline Data sour & Irce: & & & & & & \\
\hline 1 & This study & & & & & & \\
\hline 2 & Camacho (199 & & & & & & \\
\hline 3 & Young et al. & 2002) & & & & & \\
\hline$*$ & $\begin{array}{l}\text { Values errone } \\
\text { presented her }\end{array}$ & $\begin{array}{l}\text { ously publishe } \\
\text { e (personal co }\end{array}$ & $\begin{array}{l}\text { ed in Young e } \\
\text { mmunication }\end{array}$ & $\begin{array}{l}\text { al. (2002) but } \\
\text {. Camacho) }\end{array}$ & t correctl & & \\
\hline
\end{tabular}

\begin{tabular}{|c|c|c|c|c|c|c|}
\hline & & rthern & udied lo & tions & & \\
\hline \multirow{2}{*}{$\begin{array}{c}\text { Location } \\
\text { (Fig. 1) }\end{array}$} & \multirow{2}{*}{ Sample } & \multirow{2}{*}{ Lithology } & \multicolumn{2}{|c|}{ Coordinates (WGS 1984) } & \multirow{2}{*}{$\begin{array}{l}\text { Data } \\
\text { source }\end{array}$} & \multirow{2}{*}{$\begin{array}{c}\text { Th } \\
\text { (ppm) }\end{array}$} \\
\hline & & & Longitude & Latitude & & \\
\hline 6 & SW 13-321 & granite & 132,14333 & $-25,99178$ & 1 & 23 \\
\hline 6 & SW 13-322 & granite & 132,14340 & $-25,99191$ & 1 & 49 \\
\hline 3 & NW 13-134A & felsic gneiss & 131,45284 & $-25,85477$ & 1 & 34 \\
\hline 2 & SW 13-173A & felsic gneiss & 131,45334 & $-25,84543$ & 1 & 17 \\
\hline 2 & SW 13-173C & felsic gneiss & 131,45334 & $-25,84543$ & 1 & 31 \\
\hline 3 & FW 13-093 & felsic gneiss & 131,45213 & $-25,85455$ & 1 & 11 \\
\hline 4 & SW 14-006 & felsic gneiss & 131,45047 & $-25,87174$ & 1 & 20 \\
\hline 6 & SW 13-323A & felsic gneiss & 132,14344 & $-25,99211$ & 1 & 19 \\
\hline 6 & SW 14-034A & felsic gneiss & 132,14337 & $-25,99224$ & 1 & 12 \\
\hline
\end{tabular}

In group (1), samples unequivocally attributed to either the hanging wall or footwall of the Woodroffe Thrust were grouped together. This was done on the basis of their geographical position, with respective samples originating either from far into the non-mylonitized hanging wall and footwall or from the lowermost protomylonitic part of the Woodroffe Thrust. In the hanging wall, thorium concentrations range from 1 to $28 \mathrm{ppm}$ in felsic gneisses and up to $63 \mathrm{ppm}$ in granitic intrusions (higher-thorium anomalies) but are in both 
cases usually lower than $8 \mathrm{ppm}$. In the footwall, concentrations vary between 2 and $195 \mathrm{ppm}$ and are typically higher than $10 \mathrm{ppm}$ (Table 2). These concentrations are in accordance with the regional-scale contrast in thorium concentrations across the Woodroffe Thrust in the central and southern locations (Fig. 5), as well as with the results of Lambert and Heier (1968), who determined concentrations of $2.1 \mathrm{ppm}$ for the granulite facies hanging wall and $11 \mathrm{ppm}$ for the upper amphibolite facies footwall. Based on the compilation in Table 2, samples with a thorium concentration $<8 \mathrm{ppm}$ were assigned to the hanging wall and samples with higher values to the footwall of the Woodroffe Thrust. In general, samples taken close to the boundary between the mylonites and unsheared rocks of the Fregon Subdomain (typically the uppermost few tens to one hundred metres) were investigated. For the majority of samples, the assignment was straightforward since the inferred hanging wall samples are extremely low in thorium $(<3 \mathrm{ppm})$, whereas most inferred footwall samples have values $>8 \mathrm{ppm}$. Exceptions are samples SW14-243 and SW13-159, which have intermediate concentrations of 8 and $6 \mathrm{ppm}$, respectively. Both samples were assigned to the footwall since subsequent samples further towards the hanging wall (SW14-244 and SW13-161) could clearly still be attributed to the footwall. Alternatively, samples SW14-243 and SW13-159 could reflect imbrication of the Mulga Park and Fregon subdomains, but this is not supported by any field observation.

In group (2), thorium concentrations vary between 11 and 49 ppm (Table 2) but do not allow a clear distinction between samples derived from the footwall and hanging wall in a manner similar to the central and southern locations. This result is in accordance with the airborne thorium concentrations, which also do not indicate a significant jump across the Woodroffe Thrust in these more northerly locations (Fig. 5).

\subsection{Determination of boundary between hanging wall and footwall}

Measured thorium concentrations indicate that in locations 8 and 11-14 (Fig. 5) the uppermost mylonites of the Woodroffe Thrust developed in the lower-thorium Fregon Subdomain (Table 2). These results are in agreement with the proposed identification of hanging wall reworking based on field appearance. Similar field relationships, such as progressive downwards mylonitization of units clearly forming part of the hanging wall, also indicate limited reworking of the Fregon Subdomain at locations 4 and 6 (Fig. 5). However, the lack of a clear contrast in thorium concentrations between footwall and hanging wall in these locations precludes any verification of these field observations, as well as any independent determination of the thickness of hanging-wallderived mylonites in the thrust zone. We therefore excluded these northern transects when using thorium concentration as a proxy to map the original boundary between the hanging wall and footwall (Fig. 6). It was also not possible to
Table 3. Angle of dip $(\alpha)$, elevation difference $(p)$, apparent thickness $(q)$ and true thickness $(T)$ of the Woodroffe Thrust mylonites derived from the hanging wall.

\begin{tabular}{lrr|rrrr}
\hline $\begin{array}{l}\text { Location } \\
\text { (Fig. 1) }\end{array}$ & \multicolumn{2}{c|}{$\begin{array}{c}\text { Coordinates } \\
\text { (WGS 1984) }\end{array}$} & \multicolumn{4}{|c}{$\begin{array}{c}\text { Trigonometrical } \\
\text { parameters }\end{array}$} \\
\cline { 2 - 7 } & Longitude & Latitude & $\alpha\left(^{\circ}\right)$ & $p(\mathrm{~m})$ & $q(\mathrm{~m})$ & $T(\mathrm{~m})$ \\
\hline 8 & 132.143 & -25.992 & 10 & 1 & 10 & 3 \\
11 & 131.926 & -26.177 & 28 & 5 & 30 & 18 \\
12 & 131.879 & -26.212 & 21 & 22 & 55 & 40 \\
13 & 131.844 & -26.253 & - & - & - & $>0$ \\
14 & 131.774 & -26.308 & 22 & 9 & 30 & 20 \\
\hline
\end{tabular}

precisely determine the boundary at location 13 (Fig. 1), due to a large lateral gap between the last sample assigned to the footwall and the first sample assigned to the hanging wall. In an attempt to quantitatively calculate the degree of hangingwall-footwall reworking into the total mylonite zone, we applied trigonometry based on the geometrical arrangement sketched in Fig. 4a. The only modification was that the lower mylonite boundary was now defined by the newly reconstructed boundary between hanging wall and footwall. Results are summarized in Table 3. In contrast to the $250 \mathrm{~m}$ proposed by Bell (1978) for the Amata area (western edge of Fig. 1), our results indicate that only the lowermost $3 \mathrm{~m}$ of the Fregon Subdomain was reworked into the Woodroffe Thrust mylonites at location 8 , increasing up to $18-40 \mathrm{~m}$ at locations 11-14 (Fig. 1). These values represent 3-6\% of the entire thickness of the Woodroffe Thrust mylonites (Table 1) at locations 8,11 , and 14 and up to $13 \%$ at location 12 (Fig. 1). However, the difference in elevation $(p)$ is not welldefined over short distances $(q)$ given the limited $(30 \times 30 \mathrm{~m})$ resolution of the digital elevation model (ASTER). This can introduce a significant uncertainty into the calculation of the degree of hanging wall reworking. Nevertheless, our analysis clearly shows that the majority of mylonites developed in the Mulga Park Subdomain (footwall) rather than the Fregon Subdomain (hanging wall).

\section{Presence or absence of fluids during mylonitization}

The syn-deformational presence or absence of fluids in the study area is established from a series of field and thinsection observations. These include the regional variation in (1) syntectonic quartz veins, (2) the introduction of carbon, and (3) plagioclase stability and breakdown.

\subsection{Quartz veins}

Syntectonic quartz veins (Fig. 7a) and associated quartz-rich pegmatite dykes are uncommon throughout the field area, being generally absent in the southern locations and only locally present in the northern locations (Fig. 8a). These quartz veins crosscut the mylonitic fabric but were them- 


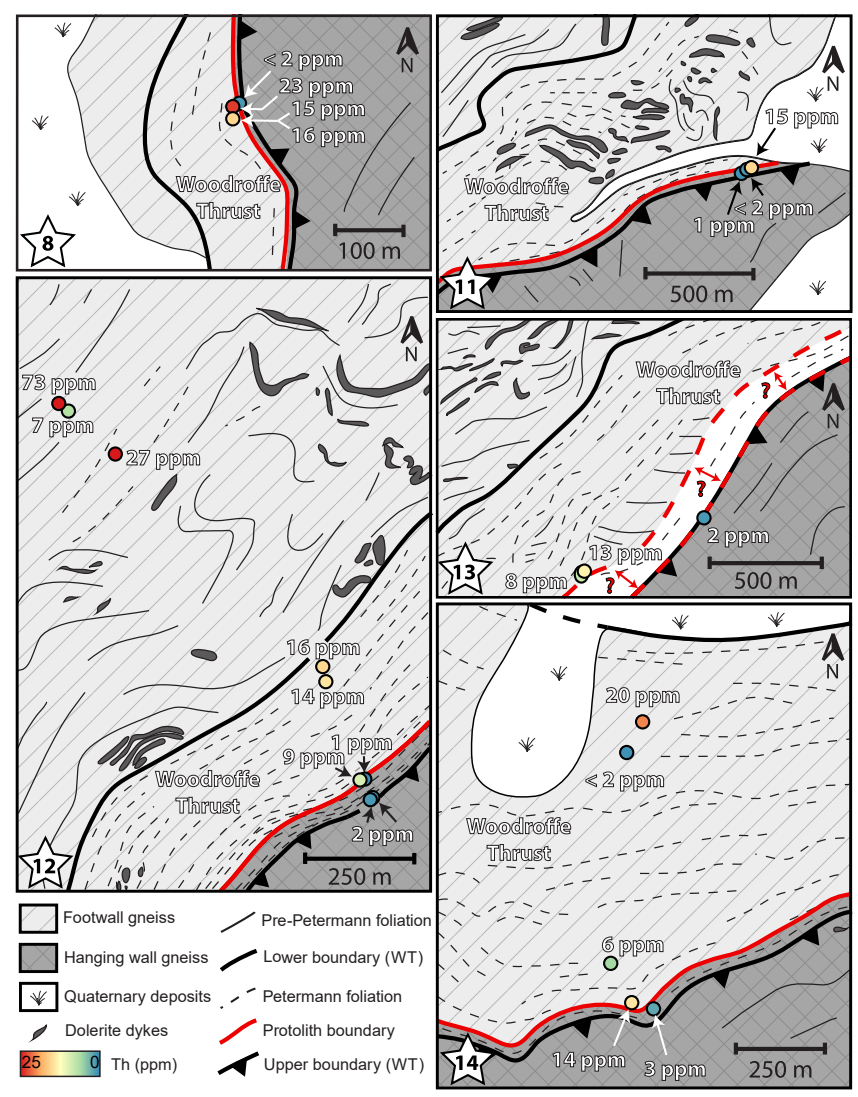

Figure 6. Sample-specific thorium (Th) concentrations (measured by $\gamma$-ray spectrometry) plotted across the Woodroffe Thrust (WT) mylonites at locations 8 and 11-14 (Fig. 1). The original boundary between the lower-thorium hanging wall and higher-thorium footwall is inferred (red line).

selves variably deformed during subsequent shearing, providing direct field evidence that they were broadly coeval with the Woodroffe Thrust and thus associated with the Petermann Orogeny. The sense of shear is both top-to-north and top-to-south, which is contrary to the dominant top-to-north shear sense associated with the Woodroffe Thrust, but it has also been documented by Bell and Johnson (1992) in the Amata region (western edge of Fig. 1). Quartz veins are boudinaged within the mylonitic foliation and, although deformed, did not preferentially localize strain (Fig. 7a, b).

\subsection{Introduction of carbon}

Finely dispersed calcite is locally found with very low modal abundance (typically $<1 \%$ ) in the otherwise noncarbonaceous rocks of the central Musgrave Block (Fig. 7c). Calcite-bearing samples are present throughout the study area but are generally more common in the north (Fig. 8b). Microstructures indicate that the fine-grained $(<10 \mu \mathrm{m}) \mathrm{cal}-$ cite nucleated during shearing (Fig. 7c). Calcium was made available from dynamic recrystallization of plagioclase to new grains with lower anorthite content (Wex et al., 2017), but carbon cannot have an immediately local source because the studied rocks were initially entirely non-carbonaceous.

\subsection{Plagioclase stability and breakdown}

Plagioclase dynamically neo-crystallized in the Woodroffe Thrust mylonites and associated shear zones (Bell and Johnson, 1989), forming typical core-and-mantle structures. The composition of the newly formed grains ranges from albite/oligoclase in felsic rocks to oligoclase/andesine in mafic rocks (Wex et al., 2017). Mineral inclusions within plagioclase clasts are common and allow the distinction of four different types of clasts, termed microstructures 1 to 4 :

1. Plagioclase studded with abundant inclusions of epidote and muscovite (Fig. 7d). This type is, with one exception, restricted to the northern locations (Fig. 8c).

2. Plagioclase containing only epidote inclusions (Fig. 7e), with a modal abundance far lower than that of epidote + muscovite inclusions of microstructure 1 . This microstructure is restricted to the central locations (Fig. 8c).

3. Plagioclase crowded with kyanite needle inclusions (Fig. 7f) (see Supporting Information B of Wex et al., 2017, for identification techniques). This microstructure is restricted to the southernmost locations (Fig. 8c).

4. Plagioclase free of inclusions (Fig. 7g). This microstructure is found in almost all locations (Fig. 8c).

Figure $8 \mathrm{c}$ shows that the type of inclusions in plagioclase varies in a N-S direction, i.e. parallel to the tectonic transport direction of the Woodroffe Thrust. From north to south, inclusions progressively change from muscovite + epidote (microstructure 1), to epidote (microstructure 2), and to kyanite (microstructure 3), with inclusion-free plagioclase clasts (microstructure 4) occurring throughout. There is no apparent variation in the type of plagioclase inclusions alongstrike of the Woodroffe Thrust (i.e. E-W).

\section{Abundance of hydrous minerals}

Pseudotachylytes have been identified as preferred discontinuities for the nucleation of ductile shear zones and strain localization under mid- to lower-crustal conditions (Andersen and Austrheim, 2006; Austrheim and Andersen, 2004; Hawemann et al., 2014, 2018; Lund and Austrheim, 2003; Menegon et al., 2017; Passchier, 1982; Pennacchioni and Cesare, 1997; Pittarello et al., 2012; Wex et al., 2014, 2017). In order to study the control of host rock mineralogy on shear initiation, the modal abundance of hydrous minerals in deformed and undeformed pseudotachylytes (representative compilation in Supplement Sect. S3) from felsic footwall and hanging wall samples was determined by image analysis of backscattered electron (BSE) 

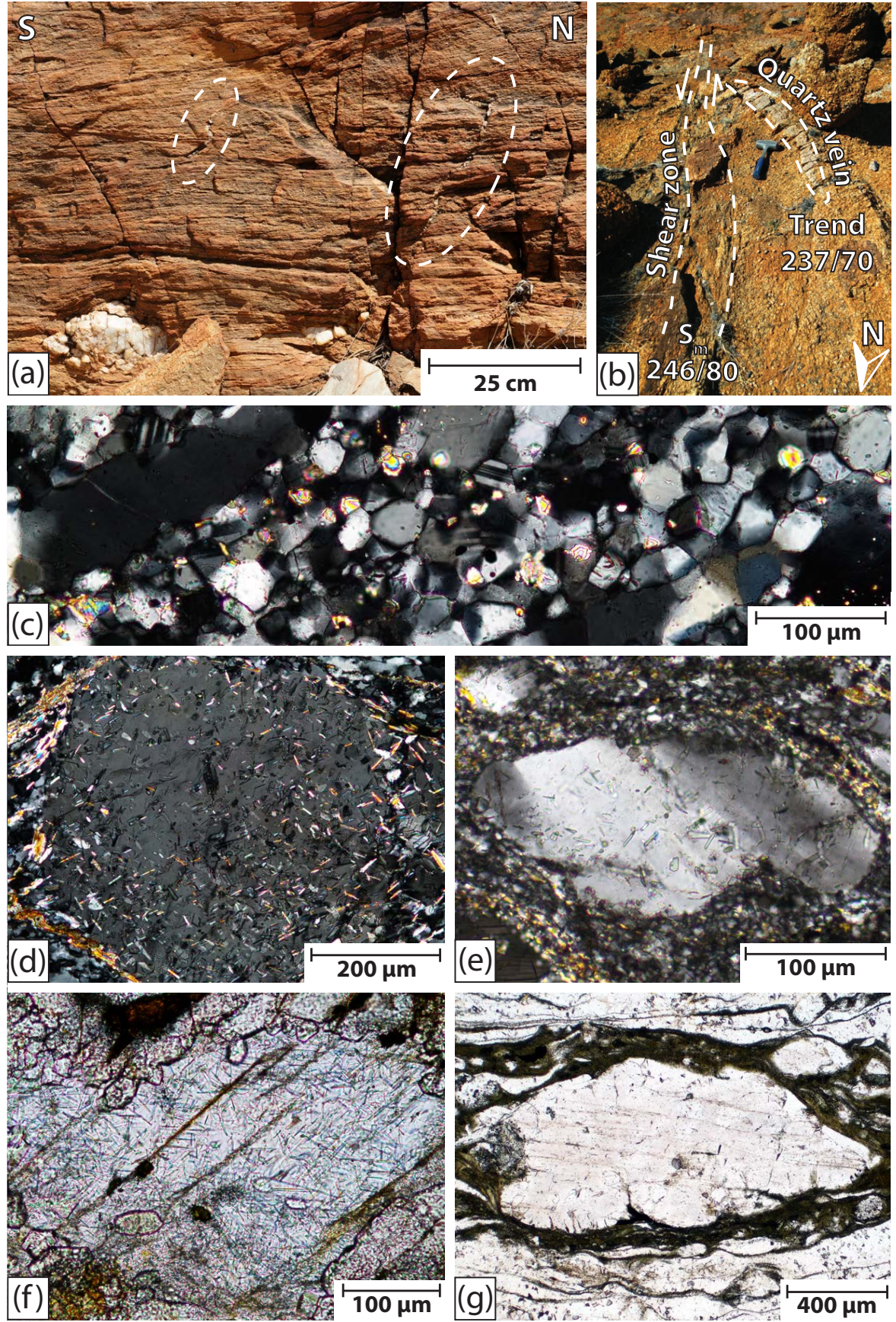

Figure 7. Field and thin-section images providing evidence for the presence or absence of fluids during deformation. (a) Quartz veins (encircled) crosscut the mylonitic foliation of the Woodroffe Thrust showing a sigmoidal shape consistent with rotation during overall top-to-north shearing. The quartz vein at the bottom of the picture is boudinaged and did not localize deformation. Outcrop NW15-264 (coordinates: 131.46883, -25.83040; location 1 in Fig. 1). (b) Quartz vein adjacent to a sinistral shear zone that is not reactivated, even though shear zone and quartz vein are almost parallel to each other. Abbreviation: $S_{\mathrm{m}}$ - mylonitic foliation. Outcrop SW13-200 (coordinates: 131.73810, -25.99564; location 9 in Fig. 1). (c) Finely dispersed calcite (high birefringence) between newly formed feldspar grains under crossed polarized light. Thin section is not oriented. Sample NW14-423A (coordinates: 131.84368, -26.11423; location 10 in Fig. 1). (d) Plagioclase clast with muscovite (higher birefringence) and epidote (lower birefringence) inclusions under crossed polarized light. Thin section is oriented N-S (left-right). Sample SW14-214A (coordinates: 131.44416, -25.90284; location 5 in Fig. 1). (e) Plagioclase clast with epidote inclusions under crossed polarized light. Thin section is oriented N-S (left-right). Sample GW13-415 (coordinates: 131.66256, -25.99928; location 8 in Fig. 1). (f) Plagioclase clast with kyanite inclusions (greenish needles) and neo-crystallized garnet under planepolarized light. Thin section is not oriented. Sample SW13-167 (coordinates: 131.77475, -26.30845; location 14 in Fig. 1). (g) Inclusion-free plagioclase clast under plane-polarized light. Thin section is oriented NNE-SSW (left-right). Sample SW13-318 (coordinates: 132.14311, -25.99142; location 6 in Fig. 1). 
(a) Development of syntectonic quartz veins

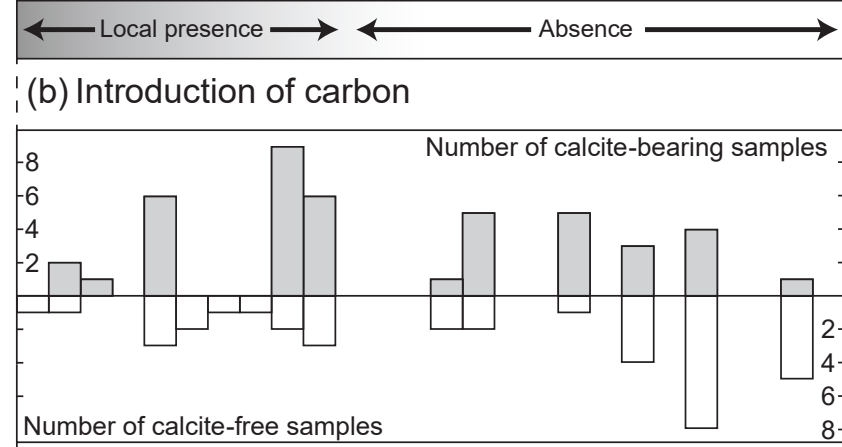

i (c) Plagioclase stability

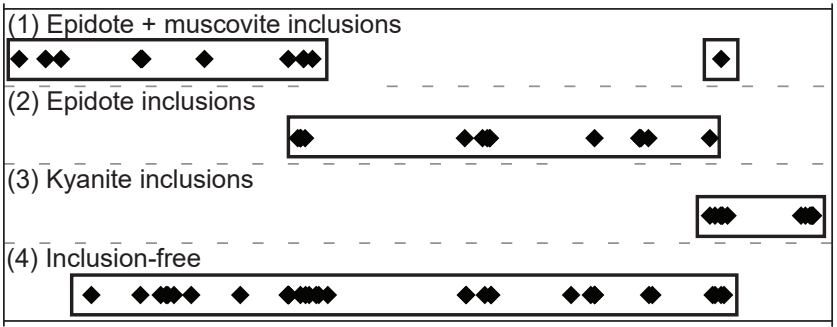

$\sim 520{ }^{\circ} \mathrm{C} \leftarrow$ Regional temperature gradient $\longrightarrow \sim 620-650{ }^{\circ} \mathrm{C}$

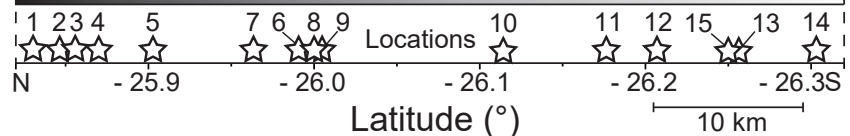

Figure 8. Regional variation in the development of (a) syntectonic quartz veins, (b) the introduction of carbon, and (c) plagioclase stability and breakdown, each plotted against sample latitude. The regional temperature gradient (Wex et al., 2017) and the position of the studied locations (Fig. 1) are indicated.

images (method outlined in Supplement Sect. S1). The different amounts of hydrous minerals in the pseudotachylytes should reflect compositional variations in the host rocks from which they formed. The results, summarized in Table 4 , indicate that matrix mineral assemblages of felsic pseudotachylytes from the hanging wall and footwall are similar to each other. These assemblages dominantly comprise $\mathrm{Pl}+\mathrm{Kfs}+\mathrm{Qz}+\mathrm{Bt}+\mathrm{Mag}+\mathrm{Ilm}$, with individual samples also containing Ep, Grt, Cpx, Opx, Ky, Ms, Rt, or Hbl. However, there is a strong contrast with regard to the modal abundance of hydrous minerals in the studied pseudotachylytes. Samples have been grouped according to their latitude coordinates, revealing that (1) the abundance of hydrous minerals decreases from north to south in both the hanging wall and the footwall and (2) at similar latitude, the footwall rocks are more hydrous than the hanging wall rocks. Two samples (SW14-029A and SW14-179) do not fit this regional trend and these outliers have been excluded in calculating the mean values, as they mask what are otherwise clear trends.

\section{Discussion}

\subsection{Plagioclase breakdown reactions}

Within the range of mid- to lower-crustal conditions, as estimated for the Woodroffe Thrust (Wex et al., 2017), the following plagioclase breakdown reactions are relevant:

$\mathrm{An}+\mathrm{Or}+\mathrm{H}_{2} \mathrm{O}=\mathrm{Ms}+\mathrm{Ep}+\mathrm{Qz}$

(Kretz, 1963; Ramberg, 1949),

$\mathrm{An}+\mathrm{Grs}+\mathrm{H}_{2} \mathrm{O}=\mathrm{Ep}+\mathrm{Qz}$

(Kretz, 1963),

$\mathrm{An}=\mathrm{Grs}+\mathrm{Ky}+\mathrm{Qz}$

(Boyd and England, 1961; Hariya and Kennedy, 1968),

$\mathrm{An}+\mathrm{H}_{2} \mathrm{O}=\mathrm{Ep}+\mathrm{Ky}+\mathrm{Qz}$

(Goldsmith, 1982; Kretz, 1963; Ramberg, 1949).

These reactions proposed in the cited publications are restricted to the system $\mathrm{Ca}-\mathrm{K}-\mathrm{Al}-\mathrm{Si}-\mathrm{OH}$ and, in particular, do not consider the presence of iron. However, iron is certainly necessary to account for the crystallization of epidote and was potentially derived from relict iron-bearing minerals (e.g. magnetite, ilmenite, biotite, or garnet). Microstructure 1 is unequivocally correlated with hydration Reaction (R1). Reaction (R2) is capable of producing microstructure 2, but garnet has been interpreted to serve as a calcium sink rather than source during the high-pressure Petermann Orogeny (Camacho et al., 2009). Alternatively, we propose that the decrease in anorthite content during plagioclase neo-crystallization (Wex et al., 2017) provided the necessary source of calcium for producing microstructure 2 . Microstructure 3 is correlated with Reaction (R3). Reactions (R3) and (R4) represent the high-pressure breakdown of plagioclase under anhydrous and hydrous conditions, respectively. According to Wayte et al. (1989), the transition between the two competing reactions occurs at a water activity of ca. 0.004 for pressure and temperature conditions similar to those in the more southerly footwall locations. In samples with microstructure 3, epidote is never observed as a secondary inclusion phase together with kyanite (Supplement Sect. S4), indicating that Reaction (R3) always prevailed over Reaction (R4).

\subsection{Fluid activity}

In the southern locations (Fig. 1), plagioclase breakdown by Reaction (R3) indicates that water was not sufficiently available to drive Reaction (R4) (Goldsmith, 1980, 1982; Wayte et al., 1989). Consequently, Reaction (R3) is a good indicator of very low water activities $(<0.004$; Wayte et al., 1989) and the absence of a free-fluid phase during deformation, since only very small amounts of water (ca. $20 \mathrm{ppm}$ ) 
Table 4. Modal abundance of hydrous minerals in felsic pseudotachylytes from the hanging wall and footwall of the Woodroffe Thrust, central Musgrave Block. Extreme outliers $\left(^{*}\right)$ are not considered. Mineral assemblages are listed in order of decreasing modal abundance (from left to right) with hydrous minerals underlined. A representative compilation of pseudotachylytes is given in Supplement Sect. S3. Errors given are $2 \times$ standard deviation.

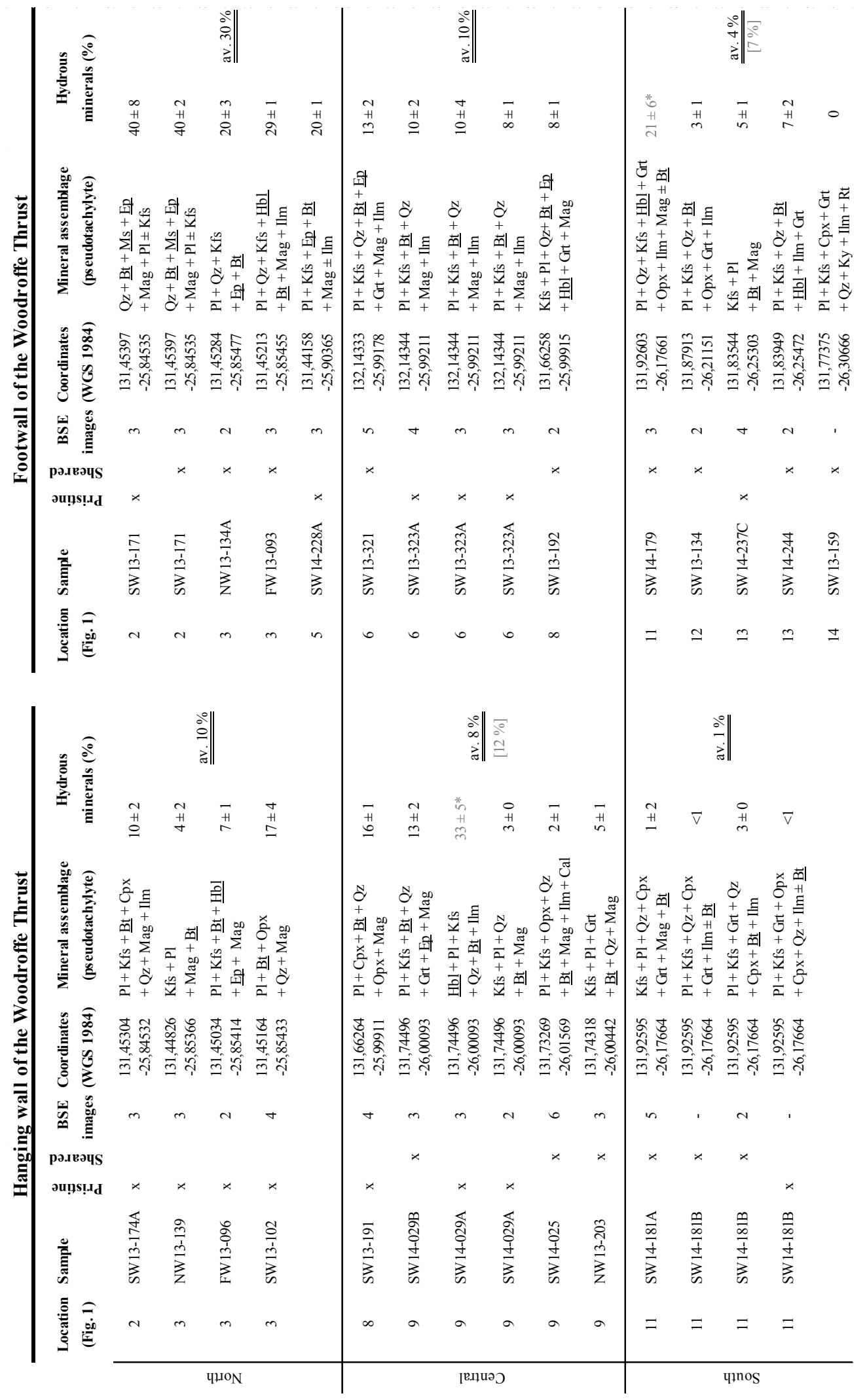


are required for mineral reactions in a solid silicate system (Milke et al., 2013). Similarly, relict plagioclase clasts without any inclusions (microstructure 4) also indicate the absence of a free-fluid phase, as the studied rocks were all metastable with respect to hydration Reactions (R1), (R2), and (R4). Consequently, any of these breakdown reactions would have rapidly consumed any available free fluid, since all other reactants were present in the studied samples. Vice versa, plagioclase breakdown by Reaction (R1) clearly indicates the presence of a free-fluid phase during deformation. Reaction (R2) also involves hydration, as indicated by the marginal presence of epidote in plagioclase clasts (microstructure 2). However, free fluids were not sufficiently available to facilitate Reaction (R1). Hence, we favour the interpretation that microstructure 2 indicates largely anhydrous conditions, with only very minor fluid introduction.

Based on the classification above, the regional availability of a free-fluid phase during deformation, termed "wet" and "dry", can be determined from the mineral inclusions in plagioclase (Fig. 8c) and the corresponding inferred breakdown reactions (Sect. 8.1). The distinction is purely qualitative and refers only to whether or not free fluid was sufficiently available to facilitate the hydrous breakdown Reaction (R1). Consequently, the studied field area is characterized as dominantly dry (microstructures 2,3 , and 4) with a progression towards locally wet conditions (microstructure 1) in most of the northernmost exposures (Fig. 9). The regional variation in (1) the development of syntectonic quartz veins (Fig. 8a) and (2) the introduction of carbon (Fig. 8b) is consistent in both cases with this interpretation (Fig. 9). However, within a single location, individual samples can have a wet microstructure 1 while others still preserve a dry microstructure 4 (Fig. 8c), indicating that the availability of fluids varied on a very local scale. Generally dry conditions are also in agreement with the fact that the metamorphic overprint during the Petermann Orogeny occurred under lower-grade conditions compared to the earlier Musgravian Orogeny and thus facilitated water consumption rather than water release.

\subsection{Fluid source}

There does not seem to be any link between the local distribution of aqueous and $\mathrm{CO}_{2}$-bearing fluids, since samples that preserve a wet microstructure 1 are not necessarily calcitebearing and vice versa (Fig. 8b, c).

Aqueous fluids infiltrating into the footwall of the Woodroffe Thrust were unlikely to have been derived from the drier hanging wall (Table 4) and consequently must originate from units within or underlying the current level of exposure of the footwall. Gneisses and granitoids in the wet northern part of the study area are clearly interleaved with and juxtaposed onto the basal units of the Amadeus Basin (Wells et al., 1970), as evident from outcrops of Dean Quartzite (Forman, 1965; Young et al., 2002) immediately west of the Kelly Hills klippe. These Neoproterozoic sed- imentary rocks represent an ideal source for aqueous and $\mathrm{CO}_{2}$-bearing fluids since they were metamorphosed and dehydrated during the Petermann Orogeny (Wells et al., 1970). However, based on regional-scale geometric reconstructions, it has been argued that the Woodroffe Thrust and potentially underlying thrust planes developed in-sequence (Wex et al., 2017). If this is true, then the Dean Quartzite was only imbricated below the northernmost studied locations after movement and deformation on the Woodroffe Thrust had largely ceased and the dynamic microstructures had already been frozen in. Therefore, we prefer a model in which the aqueous fluids were released from the granitoids and upper amphibolite facies gneisses within the footwall. Such a model is in agreement with the fact that the regional trend towards higher abundance of hydrous minerals in the north parallels the shift towards wet conditions, as indicated by the plagioclase breakdown reactions (Fig. 9). An internal source is also consistent with the conclusion that wet conditions were only present on a very local scale and that wet and dry samples are often preserved in close proximity. The same is also true of calcite-bearing and calcite-absent samples. We therefore conclude that the studied field area was not pervasively infiltrated by externally derived aqueous-rich fluids and remained a relatively closed system. The source of carbon remains unexplained, even if the quantities involved are very small. As far as currently known, units of the footwall Mulga Park Subdomain are non-carbonaceous, although small amounts of $\mathrm{CO}_{2}$ can be present within fluid inclusions. Calcite carbon and oxygen $\left(\delta^{13} \mathrm{C}_{\mathrm{Cal}}, \delta^{18} \mathrm{O}_{\mathrm{Cal}}\right)$ and carbon whole rock $\left(\delta^{13} \mathrm{C}_{\text {whole rock }}\right)$ isotropic signatures were measured with the aim of providing better constraints on the source, but the results are inconclusive (see Supplement Sect. S2 for more details). Values for $\delta^{18} \mathrm{O}$ are in agreement with calcite crystallization temperatures of $500-600{ }^{\circ} \mathrm{C}$ while $\delta^{13} \mathrm{C}_{\mathrm{Cal}}$ values are partially rock-buffered and do not allow an unequivocal interpretation of the potential source (Supplement Sect. S2).

\subsection{Distribution of ductile deformation}

The distribution of thorium establishes that the Woodroffe Thrust mylonites preferentially developed in the Mulga Park rather than the Fregon Subdomain (Fig. 6). This conclusion is in agreement with our field observations and with those of Bell and Etheridge (1976), Camacho et al. (1995), and Flottmann et al. (2004). However, it is evident from our results that in the southern locations, the lowermost hanging wall was also involved in the mylonitization process (Table 3). We discuss below the potential processes guiding the large-scale distribution of ductile deformation in the Woodroffe Thrust.

\subsubsection{Hanging wall and footwall reworking}

The proportion of the total shear strain accommodated in the narrow mylonitic to ultramylonitic zones developed in 


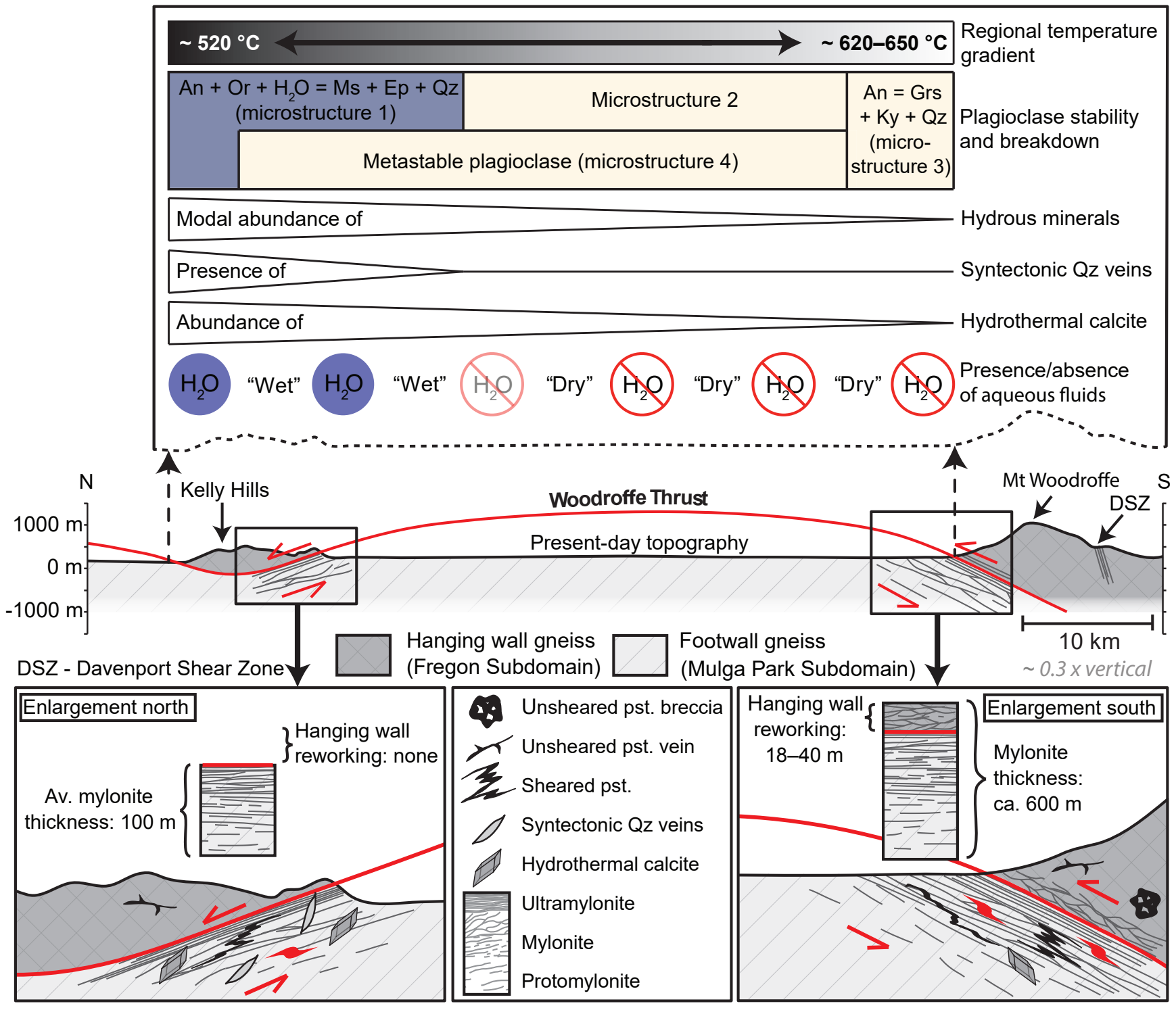

Figure 9. Projected schematic cross section through the central Musgrave Block. The horizontal scale is compressed by a factor of 3.5 with respect to the vertical scale. The regional temperature gradient is taken from Wex et al. (2017).

the lowermost hanging wall and uppermost footwall cannot be determined. However, what could be determined in this study is the relative thickness of the mylonite zones, using thorium concentrations to distinguish the original hanging wall and footwall protoliths. From this it is established that the hanging-wall-derived parts of the Woodroffe Thrust generally make up $<10 \%$ of the entire width of the mylonitic zone. This preferential development of a broader mylonite zone in the Mulga Park Subdomain footwall rather than in the Fregon Subdomain hanging wall is contrary to the expected simple model of a thrust or reverse fault system (e.g. Mancktelow, 1985; Passchier, 1984). Such a model would predict an asymmetric strain profile where the mylonite zone occurs in the initially "hotter" hanging wall rather than the "colder" footwall. An inverse distribution of ductile deformation, as a consequence of asymmetric thermal weakening, would be in agreement with the flower-like structure model proposed by Camacho and McDougall (2000) for the central Musgrave Block. Based on the preservation of prePetermann K-Ar, ${ }^{40} \mathrm{Ar}-{ }^{39} \mathrm{Ar}$, and $\mathrm{Rb}-\mathrm{Sr}$ ages in hornblende, muscovite, biotite, and K-feldspar in the undeformed gneissic country rocks, Camacho and McDougall (2000) argued that the Fregon Subdomain was rapidly buried and exhumed in less than $40 \mathrm{Myr}$. Consequently, these rocks failed to thermally equilibrate to temperatures above $350^{\circ} \mathrm{C}$ at a pressure of $\sim 1.2 \mathrm{GPa}$. With this tectonic model, the hanging wall should have been at temperatures $<350^{\circ} \mathrm{C}$ (Camacho and McDougall, 2000) and thus should have been colder than 
the footwall $\left(>500^{\circ} \mathrm{C}\right.$; Wex et al., 2017). In such a model, thermal weakening could indeed account for preferential mylonitization of the Mulga Park Subdomain. However, Wex et al. (2017) and Hawemann et al. (2018) demonstrated that Petermann Orogeny metamorphic assemblages throughout the study area are directly comparable in dynamically and statically recrystallized units, arguing that the estimated metamorphic conditions were ambient and differed little between shear zones and country rock. In addition, Wex et al. (2017) found that the syntectonic metamorphic conditions are similar in the hanging wall and footwall at the same locality, arguing against thermal weakening as a cause of the preferential mylonitization of the Mulga Park Subdomain (Camacho and McDougall, 2000).

Pseudotachylytes have been identified as preferred nucleation discontinuities for shearing under mid- to lower-crustal conditions (Andersen and Austrheim, 2006; Austrheim and Andersen, 2004; Hawemann et al., 2014; Lund and Austrheim, 2003; Menegon et al., 2017; Passchier, 1982; Pennacchioni and Cesare, 1997; Pittarello et al., 2012; Wex et al., 2014, 2017). In the Musgrave Block, however, the presence of precursor pseudotachylyte cannot account for the observed inverse distribution of ductile deformation, since these fault rocks are significantly more abundant in the hanging wall compared to the footwall (Camacho et al., 1995; Lin et al., 2005).

A potential explanation for the observed inverse gradient of ductile deformation along the Woodroffe Thrust is a rheological contrast between hanging wall and footwall assemblages, resulting in different degrees, and potentially different processes, of water-assisted weakening in quartz and feldspar (e.g. Fitz Gerald et al., 2006; Griggs, 1967, 1974; Griggs and Blacic, 1965; Hobbs, 1985; Kronenberg et al., 1990; Mancktelow and Pennacchioni, 2004; Stünitz et al., 2017; Tullis and Yund, 1989). As discussed in Sect. 8.3, the rocks in the study area represent a relatively closed system with respect to the presence or absence of aqueous fluids. The availability of aqueous fluids is thus directly linked to the abundance of hydrous minerals in these rocks, which is observed to decrease from north to south (Fig. 9). Similarly, the contrasting abundance of hydrous minerals in hanging wall and footwall (Table 4) indicates that there is consistently a higher potential for generating aqueous fluids in the footwall than in the hanging wall. If sufficient water was available, this could facilitate a preferential rheological weakening of the footwall due to new growth of micas and associated phyllonite development. However, this is not observed because the majority of the studied rocks are still relatively dry, so that only slight differences in the abundance of water could facilitate an asymmetric distribution of ductile deformation as a consequence of water-assisted weakening. The preferential mylonitization of the Mulga Park relative to the Fregon Subdomain (Fig. 6) therefore seems to be largely controlled by the precursor mineralogy established as a result of the earlier (ca. $1200 \mathrm{Ma}$ ) Musgravian Orogeny metamorphism, with peak conditions of upper amphibolite facies in the footwall but granulite facies in the hanging wall. This supports the initial hypothesis of Bell and Etheridge (1976) and Camacho et al. (1995) that a more hydrous footwall underlying an anhydrous hanging wall can facilitate an inverted gradient of ductile deformation.

\subsubsection{Variation in mylonite thickness}

Mylonite thickness in the study area does not significantly vary parallel to strike (i.e. E-W). However, from south to north, i.e. parallel to the direction of tectonic transport, the Woodroffe Thrust mylonitic zone gradually decreases in thickness from over $600 \mathrm{~m}$ to less than $100 \mathrm{~m}$ (Table 1). This potentially indicates a 6-fold increase in shear strain (and therefore average strain rate) within the mylonites, assuming a homogeneous distribution of strain and constant relative displacement across the Woodroffe Thrust thickness along the entire ca. $60 \mathrm{~km}$ transect. This trend from south to north is accompanied by a slight decrease in metamorphic temperature of ca. $100^{\circ} \mathrm{C}$ (Wex et al., 2017) and the shift from dry to relatively wet conditions, as reflected in the increasing abundance of hydrous minerals (Fig. 9). The thickness of largescale shear zones is considered to decrease with decreasing temperature and depth (Platt and Behr, 2011a, b) and decreasing displacement (Hull, 1988). A point in the footwall only enters the shear zone when it passes the toe of the thrust (that is where the thrust meets the surface). This could potentially lead to a variation in the finite shear strain experienced in the footwall. However, the whole of the exposed ca. $60 \mathrm{~km}$ $\mathrm{N}-\mathrm{S}$ section was formerly at mid- to lower-crustal level (Wex et al., 2017) and thus nowhere near the thrust toe. There is also currently no evidence for major splays of the Woodroffe Thrust into the hanging wall. Distributed folding related to the Peterman Orogeny is observable on the regional scale in the footwall (Wex et al., 2017), but the amount of shortening involved cannot be quantified. It follows that there is presently no indication of a significant change in relative displacement along the studied section and that variation in this parameter therefore cannot be used to account for the difference in mylonite thickness. It was argued above that the greater abundance of hydrous minerals in the footwall Mulga Park Subdomain compared to the hanging wall Fregon Subdomain, reflecting peak metamorphic conditions of upper amphibolite facies and granulite facies respectively during the earlier Musgravian Orogeny, resulted in slightly wetter conditions in the footwall during activity of the Woodroffe Thrust. This was proposed as an explanation for the broader zone of mylonites in the footwall. However, the current study also establishes that the thickness of the mylonitic zone decreases toward to the north and that this is associated with increasing water activity and decreasing temperature. Such an observation might reflect the possibility that even a small amount of fluid was able to weaken the footwall relative to the strong drier hanging wall, allowing it to preferentially 
take up deformation. Increasing water content in the footwall to the north could result in an increase in the effective rheological contrast between footwall and hanging wall, yielding a stronger localization toward the interface and a narrower mylonite zone that extends less into the stronger material. This hypothesis is supported by the observations in the current paper, but there is not yet a theoretical basis to provide a full explanation. Decreasing temperature to the north could also lead to increased localization and decreased shear zone thickness, both directly (Platt and Behr, 2011a, b) and as a second-order effect accentuating the rheological contrast as both footwall and hanging wall become stronger with decreasing temperature.

\section{Conclusions}

Field and thin-section observations establish that the rocks of the central Musgrave Block were predominantly dry during development of the mid-crustal Woodroffe Thrust during the ca. 560-520 Ma Petermann Orogeny, but with a progression in the thrust direction towards locally wet conditions in some of the northernmost exposures. This is indicated by (1) rare occurrence of syntectonic quartz veins and quartz-rich pegmatites (locally found only in the north), (2) the metastability of plagioclase in the presence of K-feldspar, which rarely shows significant alteration via the reaction $\mathrm{An}+\mathrm{Or}+\mathrm{H}_{2} \mathrm{O}=\mathrm{Ms}+\mathrm{Ep}+\mathrm{Qz}$ (more common towards the north), and (3) preferential high-pressure breakdown of plagioclase via the reaction $\mathrm{An}=\mathrm{Grs}+\mathrm{Ky}+\mathrm{Qz}$ (common in the southerly exposures), rather than $\mathrm{An}+\mathrm{H}_{2} \mathrm{O}=\mathrm{Ep}+\mathrm{Ky}+\mathrm{Qz}$. Aqueous fluids were most likely derived internally from hydrous minerals within the footwall gneisses and granitoids, implying that the rocks in the study area were a relatively closed system.

The thickness of the Woodroffe Thrust mylonites generally decreases with decreasing metamorphic grade and increasing availability of aqueous fluids. Atypical of a thrust, ductile deformation is more extensively developed in the footwall rocks and only marginally involved several tens of metres of the lowermost hanging wall. The inverse gradient of ductile deformation cannot be explained by thermal weakening or the distributed presence of pseudotachylyte (acting as preferred nucleation sites for shearing) but rather by preferential rheological weakening of the wetter footwall compared to the drier hanging wall. This reflects the earlier (Musgravian Orogeny) peak metamorphic conditions (granulite facies in the hanging wall and upper amphibolite facies in the footwall) and the contrasting availability of aqueous fluids derived from relict hydrous minerals in the footwall and hanging wall.
Data availability. Supplementary data are available in Supplement Sects. S1 to S4, and further information can be obtained on request from the corresponding author.

\section{The Supplement related to this article is available online at https://doi.org/10.5194/se-9-859-2018-supplement.}

Author contributions. Each of the listed authors took part in at least two of three field seasons, which formed the basis of this study. AC's previous knowledge of the Musgrave Ranges and the local communities was essential for the success of the campaign. NSM and GP developed the initial idea of the study. SW prepared the manuscript with contributions from all co-authors.

Competing interests. The authors declare that they have no conflict of interest.

Acknowledgements. We thank the communities of the Anangu Pitjantjatjara Yankunytjatjara Lands (APY) for granting us access to the Musgrave Ranges. Logistical support from the Northern Territory Geological Survey (NTGS) of Australia, Basil Tikoff (Univ. Wisconsin, Madison), and Shane and Alethea Nicolle are gratefully recognized. We further acknowledge the support of Karsten Kunze from the Scientific Center for Optical and Electron Microscopy (ScopeM) at the ETH, Zurich. Jost Eikenberg is thanked for supervising and conducting the thorium measurements at the Paul Scherrer Institute (PSI) in Villigen, Switzerland. We further acknowledge the support of Madalina Jaggi, who carried out the stable isotope analyses at the Geological Institute at ETH, Zurich. This project was financed by the Swiss National Science Foundation (SNF) grant 200021_146745 awarded to Neil S. Mancktelow, with additional funding from the University of Padova (BIRD175145/17: The geological record of deep earthquakes: the association pseudotachylyte-mylonite) awarded to Giorgio Pennacchioni.

Edited by: Renée Heilbronner

Reviewed by: Florian Fusseis and Kevin Mahan

\section{References}

Allen, J. L. and Shaw, C. A.: Seismogenic structure of a crystalline thrust fault: fabric anisotropy and coeval pseudotachylytemylonitic pseudotachylyte in the Grizzly Creek Shear Zone, Colorado, in: Geology of the Earthquake Source: A Volume in Honour of Rick Sibson, edited by: Fagereng, A., Toy, V. G., and Rowland, J. V., 135-151, Geol. Soc. Spec. Publ., 359, London, UK, 2011.

Andersen, T. B. and Austrheim, H.: Fossil earthquakes recorded by pseudotachylytes in mantle peridotite from the Alpine subduction complex of Corsica, Earth Planet. Sc. Lett., 242, 58-72, https://doi.org/10.1016/j.epsl.2005.11.058, 2006. 
Austrheim, H. and Andersen, T. B.: Pseudotachylytes from Corsica: fossil earthquakes from a subduction complex, Terra Nov., 16, 193-197, https://doi.org/10.1111/j.1365-3121.2004.00551.x, 2004.

Ballhaus, C. and Glikson, A. Y.: The petrology of layered maficultramafic intrusions of the Giles complex, western Musgrave Block, Western Australia, AGSO J. Aust. Geol. Geophys., 16, 69-90, 1995.

Bell, T. H.: Progressive deformation and reorientation of fold axes in a ductile mylonite zone: The Woodroffe Thrust, Tectonophysics, 44, 285-320, https://doi.org/10.1016/00401951(78)90074-4, 1978.

Bell, T. H. and Etheridge, M. A.: The deformation and recrystallization of quartz in a mylonite zone, central Australia, Tectonophysics, 32, 235-267, https://doi.org/10.1016/00401951(76)90064-0, 1976.

Bell, T. H. and Johnson, S. E.: The role of deformation partitioning in the deformation and recrystallization of plagioclase and K-feldspar in the Woodroffe Thrust mylonite zone, central Australia, J. Metamorph. Geol., 7, 151-168, https://doi.org/10.1111/j.1525-1314.1989.tb00582.x, 1989.

Bell, T. H. and Johnson, S. E.: Shear sense: a new approach that resolves conflicts between criteria in metamorphic rocks, J. Metamorph. Geol., 10, 99-124, https://doi.org/10.1111/j.15251314.1992.tb00074.x, 1992.

Boyd, F. R. and England, J. L.: Melting of silicates at high pressures, in: Carnegie Inst. Wash. Yr. Book 60, Port City Press, Baltimore, USA, 113-125, 1961.

Camacho, A.: An Isotopic Study of Deep-Crustal Orogenic Processes: Musgrave Block, Central Australia, PhD Thesis, The Australian National University, Canberra, Australia, 1997.

Camacho, A. and Fanning, C. M.: Some isotopic constraints on the evolution of the granulite and upper amphibolite facies terranes in the eastern Musgrave Block, central Australia, Precambrian Res., 71, 155-181, https://doi.org/10.1016/03019268(94)00060-5, 1995.

Camacho, A. and McDougall, I.: Intracratonic, strike-slip partitioned transpression and the formation and exhumation of eclogite facies rocks: An example from the Musgrave Block, central Australia, Tectonics, 19, 978-996, https://doi.org/10.1029/1999TC001151, 2000.

Camacho, A., Simons, B., and Schmidt, P. W.: Geological and palaeomagnetic significance of the Kulgera Dyke Swarm, Musgrave Block, NT, Australia, Geophys. J. Int., 107, 37-45, https://doi.org/10.1111/j.1365-246X.1991.tb01154.x, 1991.

Camacho, A., Vernon, R. H., and Fitz Gerald, J. D.: Large volumes of anhydrous pseudotachylyte in the Woodroffe Thrust, eastern Musgrave Ranges, Australia, J. Struct. Geol., 17, 371383, https://doi.org/10.1016/0191-8141(94)00069-C, 1995.

Camacho, A., Compston, W., McCulloch, M., and McDougall, I.: Timing and exhumation of eclogite facies shear zones, Musgrave Block, central Australia, J. Metamorph. Geol., 15, 735751, https://doi.org/10.1111/j.1525-1314.1997.00053.x, 1997.

Camacho, A., Yang, P., and Frederiksen, A.: Constraints from diffusion profiles on the duration of high-strain deformation in thickened crust, Geology, 37, 755-758, https://doi.org/10.1130/G25753A.1, 2009.

Camacho, A., Armstrong, R., Davis, D. W., and Bekker, A.: Early history of the Amadeus Basin: Implications for the existence and geometry of the Centralian Superbasin, Precambrian Res., 259, 232-242, https://doi.org/10.1016/j.precamres.2014.12.004, 2015.

Christie, J. M.: Moine Thrust Zone in the Assynt region of northwest Scotland, Univ. Calif. Publ. Geol. Sci., 40, 345-440, 1963.

Clarke, G. L., Buick, I. S., Glikson, A. Y., and Stewart, A. J.: Structural and pressure-temperature evolution of host rocks of the Giles Complex, western Musgrave Block, central Australia: evidence for multiple high-pressure events, AGSO J. Aust. Geol. Geophys., 16, 127-146, 1995.

Collerson, K. D., Oliver, R. L., and Rutland, R. W. R.: An example of structural and metamorphic relationships in the Musgrave orogenic belt, central Australia, J. Geol. Soc. Aust., 18, 379-393, https://doi.org/10.1080/00167617208728776, 1972.

Cooper, A. F. and Norris, R. J.: Anatomy, structural evolution, and slip rate of a plate boundary thrust: The Alpine Fault at Gaunt Creek, Westland, New Zealand, Geol. Soc. Am. Bull., 106, 627-633, https://doi.org/10.1130/00167606(1994)106<0627:ASEASR>2.3.CO;2, 1994.

Coward, M. P.: The Caledonian thrust and shear zones of N.W. Scotland, J. Struct. Geol., 2, 11-17, https://doi.org/10.1016/01918141(80)90029-2, 1980.

Davis, G. A.: Rapid upward transport of mid-crustal mylonitic gneisses in the footwall of a Miocene detachment fault, Whipple Mountains, southeastern California, Geol. Rundsch., 77, 191209, https://doi.org/10.1007/BF01848684, 1988.

Davis, G. A. and Lister, G. S.: Detachment faulting in continental extension; Perspectives from the Southwestern U.S. Cordillera, Geol. Soc. Am. Spec. Pap., 218, 133-159, https://doi.org/10.1130/SPE218-p133, 1988.

Edgoose, C. J., Camacho, A., Wakelin-King, G. A., and Simons, B. A.: $1: 250000$ Geological Map Series Explanatory Notes. Kulgera SG 53-5, 2nd ed., North. Territ. Geol. Surv., Darwin, Australia, 1993.

Edgoose, C. J., Scrimgeour, I. R., and Close, D. F.: Report 15: Geology of the Musgrave Block, Northern Territory, North. Territ. Geol. Surv., Darwin, Australia, 2004.

Ellis, D. J. and Maboko, M. A. H.: Precambrian tectonics and the physicochemical evolution of the continental crust. I. The gabbro-eclogite transition revisited, Precambrian Res., 55, 491506, https://doi.org/10.1016/0301-9268(92)90041-L, 1992.

Evins, P. M., Smithies, R. H., Howard, H. M., Kirkland, C. L., Wingate, M. T. D., and Bodorkos, S.: Record 2010/6: Redefining the Giles Event within the setting of the 1120-1020 Ma Ngaanyatjarra Rift, west Musgrave Province, central Australia, Geol. Surv. West. Aust., Perth, Australia, 2010.

Fitz Gerald, J. D., Mancktelow, N. S., Pennacchioni, G., and Kunze, K.: Ultra-fine grained quartz mylonites from high-grade shear zones: Evidence for strong dry middle to lower crust, Geology, 34, 369-372, https://doi.org/10.1130/G22099.1, 2006.

Flottmann, T., Hand, M., Close, D., Edgoose, C., and Scrimgeour, I.: Thrust Tectonic Styles of the Intracratonic Alice Springs and Petermann Orogenies, Central Australia, in: AAPG Memoir 82: Thrust tectonics and hydrocarbon systems, edited by: McClay, K. R., American Association of Petroleum Geologists (AAPG), Tulsa, USA, 538-557, 2004.

Forman, D. J.: $1: 250000$ Geological Series Explanatory Notes. Ayers Rock, N.T. SG/52-8, 1st ed., Bur. Miner. Resour. Geol. Geophys., Canberra, Australia, 1965. 
Fossen, H. and Cavalcante, G. C. G.: Shear zones - A review, Earth-Sci. Rev., 171, 434-455, https://doi.org/10.1016/j.earscirev.2017.05.002, 2017.

Goldsmith, J. R.: The melting and breakdown reactions of anorthite at high pressures and temperatures, Am. Mineral., 65, 272-284, 1980.

Goldsmith, J. R.: Plagioclase stability at elevated temperatures and water pressures., Am. Mineral., 67, 653-675, 1982.

Gray, C. M.: The Geochemistry of Central Australian Granulites in Relation to the Chemical and Isotopic Effects of Granulite Facies Metamorphism, Contrib. Mineral. Petr., 65, 79-89, https://doi.org/10.1007/BF00373573, 1977.

Gray, C. M.: Geochronology of granulite-facies gneisses in the western Musgrave Block, central Australia, J. Geol. Soc. Aust., 25, 403-414, https://doi.org/10.1080/00167617808729050, 1978.

Gray, C. M. and Compston, W.: A rubidium-strontium chronology of the metamorphism and prehistory of central Australian granulites, Geochim. Cosmochim. Ac., 42, 1735-1747, https://doi.org/10.1016/0016-7037(78)90259-4, 1978.

Griggs, D.: Hydrolytic Weakening of Quartz and Other Silicates, Geophys. J. Roy. Astr. S., 14, 19-31, https://doi.org/10.1111/j.1365-246X.1967.tb06218.x, 1967.

Griggs, D.: A Model of Hydrolytic Weakening in Quartz, J. Geophys. Res., 79, 1653-1661, https://doi.org/10.1029/JB079i011p01653, 1974.

Griggs, D. T. and Blacic, J. D.: Quartz: Anomalous Weakness of Synthetic Crystals, Science, 147, 292-295, https://doi.org/10.1126/science.147.3655.292, 1965.

Handy, M. R., Hirth, G., and Bürgmann, R.: Continental fault structure and rheology from the frictional-to-viscous transition downward, in: Tectonic Faults: Agents of Change on a Dynamic Earth, edited by: Handy, M. R., Hirth, G., and Hovius, N., MIT Press, Cambridge, USA, 139-181, 2007.

Hariya, Y. and Kennedy, G. C.: Equilibrium study of anorthite under high pressure and high temperature, Am. J. Sci., 266, 193-203, https://doi.org/10.2475/ajs.266.3.193, 1968.

Hawemann, F., Mancktelow, N., Wex, S., Camacho, A., and Pennacchioni, G.: Strain localization on different scales and the importance of brittle precursors during deformation in the lower crust (Davenport Shear Zone, Central Australia), 13th General Assembly European Geosciences Union, 27 April-2 May 2014, Vienna, Austria, Geophys. Res. Abstr., 16, 5009, 2014.

Hawemann, F., Mancktelow, N. S., Wex, S., Camacho, A., and Pennacchioni, G.: Pseudotachylyte as field evidence for lower-crustal earthquakes during the intracontinental Petermann Orogeny (Musgrave Block, Central Australia), Solid Earth, 9, 629-648, https://doi.org/10.5194/se-9-629-2018, 2018.

Heier, K. S. and Adams, J. A. S.: Concentration of radioactive elements in deep crustal material, Geochim. Cosmochim. Ac., 29, 53-61, https://doi.org/10.1016/0016-7037(65)90078-5, 1965.

Hobbs, B. E.: The hydrolytic weakening effect in quartz, in: Point Defects in Minerals, edited by: Schock, R. N., Am. Geophys. Union, Geophys. Monogr. Ser., 31, Washington D.C., USA, 151170, 1985.

Hull, J.: Thickness-displacement relationships for deformation zones, J. Struct. Geol., 10, 431-435, https://doi.org/10.1016/0191-8141(88)90020-X, 1988.
Kretz, R.: Note on some equilibria in which plagioclase and epidote participate, Am. J. Sci., 261, 973-982, https://doi.org/10.2475/ajs.261.10.973, 1963.

Kronenberg, A. K., Segall, P., and Wolf, G. H.: Hydrolytic Weakening and Penetrative Deformation Within a Natural Shear Zone, in: The Brittle-Ductile Transition in Rocks, edited by: Duba, A. G., Durham, W. B., Handin, J. W., and Wang, H. F., Am. Geophys. Union, Geophys. Monogr. Ser., 56, Washington D.C., USA, 21-36, 1990.

Lambert, I. B. and Heier, K. S.: The vertical distribution of uranium, thorium and potassium in the Continental Crust, Geochim. Cosmochim. Ac., 31, 377-390, https://doi.org/10.1016/00167037(67)90048-8, 1967.

Lambert, I. B. and Heier, K. S.: Geochemical investigations of deep-seated rocks in the Australian shield, Lithos, 1, 30-53, https://doi.org/10.1016/S0024-4937(68)80033-7, 1968.

Lin, A., Maruyama, T., Aaron, S., Michibayashi, K., Camacho, A., and Kano, K.: Propagation of seismic slip from brittle to ductile crust: Evidence from pseudotachylyte of the Woodroffe thrust, central Australia, Tectonophysics, 402, 21-35, https://doi.org/10.1016/j.tecto.2004.10.016, 2005.

Lund, M. G. and Austrheim, H.: High-pressure metamorphism and deep-crustal seismicity: evidence from contemporaneous formation of pseudotachylytes and eclogite facies coronas, Tectonophysics, 372, 59-83, https://doi.org/10.1016/S00401951(03)00232-4, 2003.

Maboko, M. A. H., McDougall, I., and Zeitler, P. K.: Metamorphic P-T path of granulites in the Musgrave Ranges, central Australia, in: Evolution of Metamorphic Belts, edited by: Daly, J. S., Cliff, R. A., and Yardley, B. W. D., Geol. Soc. Spec. Publ., 43, London, UK, 303-307, 1989.

Maboko, M. A. H., Williams, I. S., and Compston, W.: Zircon U-Pb Chronometry of the Pressure and Temperature History of Granulites in the Musgrave Ranges, Central Australia, J. Geol., 99, 675-697, 1991.

Maboko, M. A. H., McDougall, I., Zeitler, P. K., and Williams, I. S.: Geochronological evidence for $\sim 530-550$ Ma juxtaposition of two Proterozoic metamorphic terranes in the Musgrave Ranges, central Australia, Aust. J. Earth Sci., 39, 457-471, https://doi.org/10.1080/08120099208728038, 1992.

Major, R. B.: Woodroffe Thrust Zone in the Musgrave Ranges, Q. Geol. Notes, 35, 9-11, 1970.

Major, R. B.: Explanatory Notes for the Woodroffe $1: 250000 \mathrm{Ge}-$ ological Map SG/52-12, 1st ed., Geol. Surv. South Aust., Adelaide, Australia, 1973.

Major, R. B. and Conor, C. H. H.: Musgrave Block, in: Bulletin 54: The geology of South Australia, vol. 1. The Precambrian, edited by: Drexel, J. F., Preiss, W. V., and Parker, A. J., Geol. Surv. South Aust., Adelaide, Australia, 156-167, 1993.

Major, R. B., Johnson, J. E., Leeson, B., Mirams, R. C., and Thomson, B. P.: $1: 250000$ S. A. Geological Atlas Series Sheet. Woodroffe SG 52-12 Zone 4., 1st ed., Geol. Surv. South Aust., Adelaide, Australia, 1967.

Mancktelow, N.: The Simplon Line: a major displacement zone in the western Lepontine Alps, Eclogae Geol. Helv., 78, 73-96, https://doi.org/10.5169/seals-165644, 1985.

Mancktelow, N. S. and Pennacchioni, G.: The influence of grain boundary fluids on the microstructure of 
quartz-feldspar mylonites, J. Struct. Geol., 26, 47-69, https://doi.org/10.1016/S0191-8141(03)00081-6, 2004.

Mancktelow, N. S. and Pennacchioni, G.: The control of precursor brittle fracture and fluid-rock interaction on the development of single and paired ductile shear zones, J. Struct. Geol., 27, 645661, https://doi.org/10.1016/j.jsg.2004.12.001, 2005.

Menegon, L., Pennacchioni, G., Malaspina, N., Harris, K., and Wood, E.: Earthquakes as Precursors of Ductile Shear Zones in the Dry and Strong Lower Crust, Geochem. Geophy. Geosy., 18, 4356-4374, https://doi.org/10.1002/2017GC007189, 2017.

Milke, R., Neusser, G., Kolzer, K., and Wunder, B.: Very little water is necessary to make a dry solid silicate system wet, Geology, 41, 247-250, https://doi.org/10.1130/G33674.1, 2013.

Myers, J. S., Shaw, R. D., and Tyler, I. M.: Tectonic evolution of Proterozoic Australia, Tectonics, 15, 1431-1446, https://doi.org/10.1029/96TC02356, 1996.

Passchier, C. W.: Pseudotachylyte and the development of ultramylonite bands in the Saint-Barthélemy Massif, French Pyrenees, J. Struct. Geol., 4, 69-79, https://doi.org/10.1016/01918141(82)90008-6, 1982

Passchier, C. W.: Mylonite-dominated footwall geometry in a shear zone, central Pyrenees, Geol. Mag., 121, 429-436, https://doi.org/10.1017/S0016756800029964, 1984.

Passchier, C. W. and Trouw, R. A. J.: Microtectonics, 2nd ed., Springer, Berlin, Heidelberg, Germany, 2005.

Pennacchioni, G. and Cesare, B.: Ductile-brittle transition in preAlpine amphibolite facies mylonites during evolution from water-present to water-deficient conditions (Mont Mary nappe, Italian Western Alps), J. Metamorph. Geol., 15, 777-791, https://doi.org/10.1111/j.1525-1314.1997.00055.x, 1997.

Percival, P. J.: Record 2010/13: Index of Airborne Geophysical Surveys, 11th ed., Geoscience Australia, Canberra, Australia, 2010.

Pittarello, L., Pennacchioni, G., and Di Toro, G.: Amphibolitefacies pseudotachylytes in Premosello metagabbro and felsic mylonites (Ivrea Zone, Italy), Tectonophysics, 580, 43-57, https://doi.org/10.1016/j.tecto.2012.08.001, 2012.

Platt, J. P. and Behr, W. M.: Deep structure of lithospheric fault zones, Geophys. Res. Lett., 38, 1-6, https://doi.org/10.1029/2011GL049719, 2011a.

Platt, J. P. and Behr, W. M.: Lithospheric shear zones as constant stress experiments, Geology, 39, 127-130, https://doi.org/10.1130/G31561.1, 2011b.

Ramberg, H.: The Facies Classification of Rocks: A Clue to the Origin of Quartzo-Feldspathic Massifs and Veins, J. Geol., 57, 18-54, https://doi.org/10.1086/625573, 1949.

Ramsay, J. G.: Shear zone geometry: A review, J. Struct. Geol., 2, 83-99, https://doi.org/10.1016/0191-8141(80)90038-3, 1980.

Schmidt, P. W., Williams, G. E., Camacho, A., and Lee, J. K. W.: Assembly of Proterozoic Australia: Implications of a revised pole for the $\sim 1070 \mathrm{Ma}$ Alcurra Dyke Swarm, central Australia, Geophys. J. Int., 167, 626-634, https://doi.org/10.1111/j.1365246X.2006.03192.x, 2006.

Scrimgeour, I. and Close, D.: Regional high-pressure metamorphism during intracratonic deformation: The Petermann Orogeny, central Australia, J. Metamorph. Geol., 17, 557-572, https://doi.org/10.1046/j.1525-1314.1999.00217.x, 1999.

Scrimgeour, I. R., Close, D. F., and Edgoose, C. J.: $1: 250000 \mathrm{Ge}-$ ological Map Series and Explanatary Notes. Petermann Ranges
SG52-7, 2nd ed., North. Territ. Geol. Surv., Darwin, Australia, 1999.

Selverstone, J., Axen, G. J., and Luther, A.: Fault localization controlled by fluid infiltration into mylonites: Formation and strength of low-angle normal faults in the midcrustal brittle-plastic transition, J. Geophys. Res., 117, B06210, https://doi.org/10.1029/2012JB009171, 2012.

Sibson, R. H., White, S. H., and Atkinson, B. K.: Structure and distribution of fault rocks in the Alpine Fault Zone, New Zealand, in: Thrust and Nappe Tectonics, edited by: McClay, K. R. and Price, N. J., Geol. Soc. Spec. Publ., 9, London, UK, 197-210, 1981.

Smithies, R. H., Howard, H. M., Evins, P. M., Kirkland, C. L., Kelsey, D. E., Hand, M., Wingate, M. T. D., Collins, A. S., and Belousova, E.: High-Temperature Granite Magmatism, CrustMantle Interaction and the Mesoproterozoic Intracontinental Evolution of the Musgrave Province, Central Australia, J. Petrol., 52, 931-958, https://doi.org/10.1093/petrology/egr010, 2011

Sprigg, R. C., Wilson, B., Coats, R. P., Webb, B. P., and O'Driscoll, E. S.: 4 Mile Geological Series Sheet. Alberga G 53-9 Zone 4, 1st ed., Geol. Surv. South Aust., Adelaide, Australia, 1959.

Stewart, A. J.: Western extension of the Woodroffe Thrust, Musgrave Block, central Australia, AGSO J. Aust. Geol. Geophys., 16, 147-153, 1995.

Stewart, A. J.: Record 1997/5: Geology of the Bates 1:100000 Sheet Area (4646), Musgrave Block, Western Australia, 1st ed., Aust. Geol. Surv. Organ., Canberra, Australia, 1997.

Stünitz, H., Thust, A., Heilbronner, R., Behrens, H., Kilian, R., Tarantola, A., and Fitz Gerald, J. D.: Water redistribution in experimentally deformed natural milky quartz single crystals Implications for $\mathrm{H}_{2} \mathrm{O}$-weakening processes, J. Geophys. Res.Sol. Ea., 122, 866-894, https://doi.org/10.1002/2016JB013533, 2017.

Sun, S. and Sheraton, J.: Zircon U/Pb chronology, tectono-thermal and crust-forming events in the Tomkinson Ranges, Musgrave Block, Central Australia, AGSO Res. Newsl., 17, 9-11, 1992.

Sun, S., Sheraton, J. W., Glikson, A. Y., and Stewart, A. J.: A major magmatic event during 1050-1080 Ma in central Australia, and an emplacement age for the Giles Complex, AGSO Res. Newsl., 24, 13-15, 1996.

Tucker, N. M. T., Hand, M., Kelsey, D. E., and Dutch, R. A.: A duality of timescales: Short-lived ultrahigh temperature metamorphism preserving a long-lived monazite growth history in the Grenvillian MusgraveAlbany-Fraser Orogen, Precambrian Res., 264, 204-234, https://doi.org/10.1016/j.precamres.2015.04.015, 2015.

Tullis, J. and Yund, R. A.: Hydrolytic weakening of quartz aggregates: The effects of water and pressure on recovery, Geophys. Res. Lett., 16, 1343-1346, https://doi.org/10.1029/GL016i011p01343, 1989.

Walsh, A. K., Kelsey, D. E., Kirklan, C. L., Hand, M., Smithies, R. H., Clark, C., and Howard, H. M.: P-T-t evolution of a large, long-lived, ultrahigh-temperature Grenvillian belt in central Australia, Gondwana Res., 28, 531-564, https://doi.org/10.1016/j.gr.2014.05.012, 2015.

Wayte, G. J., Worden, R. H., Rubie, D. C., and Droop, G. T. R.: A TEM study of disequilibrium plagioclase breakdown at high pressure: the role of infiltrating fluid, Contrib. Mineral. Petr., 101, 426-437, https://doi.org/10.1007/BF00372216, 1989. 
Wells, A. T., Forman, D. J., Ranford, L. C., and Cook, P. J.: Bulletin 100: Geology of the Amadeus Basin, Central Australia, Bur. Miner. Resour. Geol. Geophys., Canberra, Australia, 1970.

Wex, S., Mancktelow, N., Hawemann, F., Camacho, A., and Pennacchioni, G.: Pseudotachylyte formation vs. mylonitization repeated cycles of seismic fracture and aseismic creep in the middle crust (Woodroffe Thrust, Central Australia), 13th General Assembly European Geosciences Union, 27 April-2 May 2014, Vienna, Austria, Geophys. Res. Abstr., 16, 5071, 2014.

Wex, S., Mancktelow, N. S., Hawemann, F., Camacho, A., and Pennacchioni, G.: Geometry of a large-scale, low-angle, midcrustal thrust (Woodroffe Thrust, central Australia), Tectonics, 36, 2447-2476, https://doi.org/10.1002/2017TC004681, 2017.

Whitney, D. L. and Evans, B. W.: Abbreviations for names of rock-forming minerals, Am. Mineral., 95, 185-187, https://doi.org/10.2138/am.2010.3371, 2010.
Young, D. N., Duncan, N., Camacho, A., Ferenczi, P. A., and Madigan, T. L. A.: $1: 250000$ Geological Map Series and Explanatory Notes. Ayers Rock SG 52-8, 2nd ed., North. Territ. Geol. Surv., Darwin, Australia, 2002.

Zhao, J. and McCulloch, M. T.: Sm-Nd mineral isochron ages of Late Proterozoic dyke swarms in Australia: evidence for two distinctive events of mafic magmatism and crustal extension, Chem. Geol., 109, 341-354, https://doi.org/10.1016/00092541(93)90079-X, 1993.

Zhao, J., McCulloch, M. T., and Korsch, R. J.: Characterisation of a plume-related $\sim 800 \mathrm{Ma}$ magmatic event and its implications for basin formation in central-southern Australia, Earth Planet. Sc. Lett., 121, 349-367, https://doi.org/10.1016/0012821X(94)90077-9, 1994. 